\title{
Speciation and concentrations of dissolved nitrogen as determinants of brown tide Aureococcus anophagefferens bloom initiation
}

\author{
Gordon T. Taylor ${ }^{1, *}$, Christopher J. Gobler ${ }^{2}$, Sergio A. Sañudo-Wilhelmy ${ }^{1}$ \\ ${ }^{1}$ Marine Sciences Research Center, Stony Brook University, Stony Brook, New York 11794-5000, USA \\ ${ }^{2}$ Marine Science Program, Southampton College of Long Island University, Southampton, New York 11968, USA
}

\begin{abstract}
Growth responses of the brown tide organism Aureococcus anophagefferens and 4 cooccurring microalgal species to varying concentrations of nitrate, ammonium, urea, and glutamate were assayed in laboratory experiments. Analogous to seasonal shifts in nutrient regimes in local bays, growth functional responses were used to predict relative species abundances in simulated communities supported by a reduced nitrogen source after cultivation on $\mathrm{NO}_{3}{ }^{-}$. Simulations were based on Monod kinetic parameters, lagged growth responses and threshold nutrient concentrations. Presented with $\mathrm{NO}_{3}{ }^{-}$only, rank order of biomass production was Thalassiosira pseudonana $>$Nannochloris atomus $>$ Synechococcus bacillaris $>$ Prorocentrum minimum $>$ A. anophagefferens at all concentrations. In contrast, model communities offered $\mathrm{NH}_{4}{ }^{+}$or glutamate at most environmental concentrations ( 1 to $50 \mu \mathrm{M} \mathrm{N}$ ) tended to be dominated by $A$. anophagefferens and $P$. minimum. Over environmental ranges of urea concentrations (1 to $50 \mu \mathrm{M} \mathrm{N}$ ), T. pseudonana grew fastest, followed by $A$. anophagefferens. In field validation experiments, bay water with bloom concentrations of $A$. anophagefferens $\left(10^{5}\right.$ cells $\left.\mathrm{ml}^{-1}\right)$ amended with equimolar (total $\mathrm{N}$ ) nitrate-rich groundwater or reduced N-rich sediment porewater supported equal increases in total chlorophyll a through time. However, porewater selectively stimulated $A$. anophagefferens growth more than groundwater, and the converse was observed for cyanobacteria. Extrapolation of all experimental results to conditions in Long Island embayments suggests that phytoplankton communities supplied primarily with $\mathrm{NO}_{3}{ }^{-}$ will be dominated by diatoms, such as T. pseudonana, and perhaps by chlorophytes and cyanobacteria like $N$. atomus and $S$. bacillaris. Conversely, phytoplankton communities primarily supplied with low-to-moderate concentrations of reduced $\mathrm{N}$-species, $\mathrm{NH}_{4}{ }^{+}$, and dissolved organic nitrogen (DON) will be dominated by $A$. anophagefferens and, to a lesser extent, dinoflagellates like $P$. minimum. Our results are consistent with published field observations of $A$. anophagefferens bloom dynamics in Long Island estuaries.
\end{abstract}

KEY WORDS: Aureococcus anophagefferens - Bottom-up control - Brown tide Nitrogen uptake · Pelagophyceae $\cdot$ Submarine groundwater discharge

\section{INTRODUCTION}

Brown tide (BT), a harmful algal bloom caused by proliferation of the pelagophyte Aureococcus anophagefferens Hargraves et Sieburth has afflicted the Peconic and Great South Bay estuaries of Long Island (New York, USA) almost annually since 1985. These bays possess the requisite physico-chemical conditions to support massive phytoplankton blooms: long hydro- logic residence times, shallow and well-lit water columns, and substantial nutrient loadings from a densely populated watershed. However, a robust explanation for why almost unialgal blooms of $A$. anophagefferens recur with such regularity in these embayments, but only sporadically elsewhere along the mid-Atlantic M.S. seaboard, has yet to be validated. Uncoupled spatial and temporal distributions of nutrients and $A$. anophagefferens argue against BT 
merely resulting from coastal eutrophication (Cosper et al. 1989b). Clearly, subtle selective pressures are operative, permitting faster growth and/or slower removal of $A$. anophagefferens relative to other competing phytoplankters that commonly inhabit these embayments.

Hypotheses that invoke either bottom-up or topdown control have been advanced to explain onset and persistence of the $\mathrm{BT}$, but none have proven to be entirely satisfactory (reviewed in Bricelj \& Lonsdale 1997). Among the bottom-up hypotheses, connections between BT and meteorological and hydrological processes have been inferred (Nixon et al. 1994, LaRoche et al. 1997). Cosper et al. (1987) reported that selected blooms coincided with unusual drought periods. LaRoche et al. (1997) noted an inverse correlation between $\mathrm{BT}$ outbreaks and submarine groundwater discharge (SGD) in an $11 \mathrm{yr}$ series of field observations. SGD is the primary pathway for freshwater entry into many estuaries, similar to the Peconic and Great South Bays, and carries with it high concentrations of nutrients - especially $\mathrm{NO}_{3}{ }^{-}$- from the watershed (LaRoche et al. 1997, Paerl 1997, Gobler \& Sañudo-Wilhelmy 2001a). These observations are consistent with the hypothesis that SGD introduces materials that alter selective pressures on phytoplankton in these embayments and thereby controls phytoplankton dynamics, although the primary mechanism(s) is yet to be fully elucidated. Materials introduced into these embayments may preferentially stimulate or inhibit growth of populations within the phytoplankton community directly, or set up environmental conditions so that a succession of events leads to BT onset (Berg et al. 1997). A SGD-related explanation is appealing because quantifiable changes in these land-linked ecosystems between the pre-BT (before 1985) and BT eras can be related to human population growth and land use (LaRoche et al. 1997).

LaRoche et al. (1997) observed ebbing SGD in the summer of 1995 prior to build up of dissolved organic nitrogen (DON) concentrations, which subsequently became depleted as Aureococcus anophagefferens abundances rose at 2 stations within the Peconic estuary. Their time-series analyses led to postulation that A. anophagefferens gained competitive advantages over other microalgae because of its efficient DON utilization (Dzurica et al. 1989, Berg et al. 1997, 2002, Lomas et al. 2001, Mulholland et al. 2002). Gobler \& Sañudo-Wilhelmy (2001a) observed that BT was a secondary bloom in West Neck Bay, Long Island, apparently supported by reduced forms of nitrogen. Consistent with LaRoche et al.'s (1997) observations, these authors hypothesized that in late spring/early summer, a mixed algal bloom was stimulated by accelerated input of nitrate-laden SGD that was hydraulically forced into these bays by spring rains. As the bloom depleted $\mathrm{NO}_{3}{ }^{-}$, trophic interactions in the water column, in addition to heterotrophic metabolism and diagenetic processes in sediments, regenerated reduced forms of dissolved nitrogen, $\mathrm{NH}_{4}{ }^{+}$, urea and other DON, which then became the dominant $\mathrm{N}$-species available to phytoplankton as SGD ebbed. In turn, the shift in available $\mathrm{N}$-species exerted a new set of selective pressures favoring onset of $\mathrm{BT}$ and perhaps competitive exclusion of other species.

It is well established that relative availabilities of macronutrients (N:P:Si stoichiometries) can shape phytoplankton community composition based on individual species' nutrient requirements, uptake capabilities, and inter-specific competition for resources (Tilman 1976, 1982, Smayda 1989, Schöllhorn \& Granéli 1996, Carlsson \& Granéli 1999). Field studies have demonstrated that microalgal taxa prefer particular forms of a given nutrient element (Berg et al. 1997, 2001, 2003a, Lomas et al. 1996, 2001). For example, Aureococcus anophagefferens has been shown to proliferate faster in $\mathrm{NH}_{4}{ }^{+}$or urea-amended water than in water with $\mathrm{NO}_{3}{ }^{-}$amendments, while diatoms tend to grow fastest in waters with high $\mathrm{NO}_{3}{ }^{-}$fluxes (Berg et al. 1997, Collos et al. 1997). The present study examines the hypothesis that nitrogen speciation in Long Island embayments controls phytoplankton community composition through resource competition. Specifically, we tested the hypothesis that, barring other resource limitations, A. anophagefferens has a competitive advantage over other indigenous phytoplankton species when reduced nitrogen species $\left(\mathrm{NH}_{4}{ }^{+}\right.$, urea, and other DON) supplant $\mathrm{NO}_{3}{ }^{-}$as the dominant dissolved nitrogen species. We compared growth rates of $A$. anophagefferens cultures with 4 other algal species incubated in parallel over concentration ranges of nitrate, ammonium, urea, and glutamate (an example of DON). Analogous to field conditions described in LaRoche et al. (1997) and Gobler \& Sañudo-Wilhelmy (2001a), we examined algal response to transition from $\mathrm{NO}_{3}{ }^{-}$-supported growth to that supported by reduced $\mathrm{N}$ species. Algae used in these experiments span broad phylogenetic distances and include a chlorophyte, dinoflagellate, cyanobacterium, diatom, and pelagophyte, all of which are common to these coastal embayments. Monod functional responses were derived from growth curves, and simple predictive simulations were run to determine which species would dominate a phytoplankton community under constant nutrient availability and in the absence of topdown control or other limitations. Using bay water experiencing a BT, we then compared model predictions with actual community responses to equimolar amendments of nitrate-rich groundwater and reduced $\mathrm{N}$-rich benthic porewater. 


\section{MATERIALS AND METHODS}

Phytoplankton cultures. All phytoplankton clones used in this study were originally isolated from coastal waters of Long Island and were obtained from the Provasoli-Guillard Center for Culture of Marine Phytoplankton (CCMP; http://ccmp.bigelow.org). Although maintained as unialgal cultures, they were never axenic. Epifluorescent microscopic inspection of DAPIstained preparations confirmed that bacterial abundances in cultures usually remained an order of magnitude lower than those of algae from one transfer to the next until the late stationary phase, and were equivalent to $\sim 0.4$ to $3 \%$ of algal N-biomass. Aureococcus anophagefferens (CCMP 1708) was originally isolated from West Neck Bay (Fig. 1). The chlorophyte and dinoflagellate, Nannochloris atomus Butcher (CCMP 509; Clone Synonym: GSBNANNO) and Prorocentrum minimum Schiller (CCMP 696; Clone Synonym: NEPCC541), respectively, were isolated from Great South Bay. The cyanobacterium Synechococcus bacillaris Butcher (CCMP 1333; Clone Synonyms: WH5701 and NEPCC539) was collected from Long Island Sound off Milford, Connecticut. The centric diatom Thalassiosira pseudonana Hasle et Heimdal (CCMP 1335; Clone Synonym: NEPCC58) was isolated from Moriches Bay, Long Island (Fig. 1).

All microalgal cultures were grown in BT medium, a modified f/2 medium (Guillard \& Ryther 1962). Maintenance medium was prepared from filtered $(0.22 \mu \mathrm{m})$ Atlantic Ocean seawater collected $8 \mathrm{~km}$ southeast of the Shinnecock Inlet, near the east end of Long Island, and had a salinity of $34 \mathrm{psu}$. BT medium differed from the published $\mathrm{f} / 2$ medium in that it contained $10^{-8} \mathrm{M}$ selenium as selenite, citric acid was substituted for
EDTA as the metals chelator, and Fe concentrations were $10^{-6} \mathrm{M}$ (Cosper et al. 1993). Semi-complete medium was autoclaved for $15 \mathrm{~min}$ in $125 \mathrm{ml}$ Pyrex erlenmeyer flasks. After cooling, filter-sterilized vitamin and phosphate stocks were aseptically transferred to each flask. Final concentrations of nitrate, phosphate and silicate in the maintenance medium were 883, 36, and $110 \mu \mathrm{M}$, respectively. Using spectrophotometric techniques (Valderrama 1981, Jones 1984, Parsons et al. 1984), we determined that background levels of $\mathrm{DON}, \mathrm{NO}_{3}{ }^{-}, \mathrm{NO}_{2}{ }^{-}$, and $\mathrm{NH}_{4}{ }^{+}$in our basal seawater were $8.9 \pm 0.8,0.15 \pm 0.05,0.0 \pm 0.0$, and $0.23 \pm 0.05 \mu \mathrm{M} \mathrm{N}( \pm 1 \mathrm{SD})$, respectively. Cultures were maintained at $20^{\circ} \mathrm{C}$ on a $14: 10 \mathrm{~h}$ light:dark cycle, illuminated by a bank of $6 \times 20 \mathrm{~W}$ fluorescent lights that provided 48 to $63 \mu \mathrm{mol}$ quanta $\mathrm{m}^{-2} \mathrm{~s}^{-1}$ to culture flasks in a highly reflective incubator. These conditions approximated temperature and light exposures found in Long Island estuaries during early summer months when Aureococcus anophagefferens blooms occur (Cosper et al. 1989a, Milligan \& Cosper 1997). Light exposures approximated the half-saturating irradiances $\left(K_{\mathrm{lt}}\right)$ determined for $A$. anophagefferens cultures (69 $\mathrm{\mu mol}$ quanta $\mathrm{m}^{-2} \mathrm{~s}^{-1}$; Milligan \& Cosper 1997), but surpassed $K_{\mathrm{lt}}$ observed in field blooms (1.1 to $12.8 \mu \mathrm{mol}$ quanta $\mathrm{m}^{-2} \mathrm{~s}^{-1}$; Lomas et al. 1996).

Grow out experiments. Algal responses to nitrogen speciation and concentration were examined in parallel incubations of all 5 species, each provided with 6 concentrations of a primary $\mathrm{N}$-source in $100 \mathrm{ml}$ of the BT medium described above. For the nitrate experiment, a separate series of $125 \mathrm{ml}$ Pyrex flasks was prepared for each algal species with 6 diminishing $\mathrm{NO}_{3}{ }^{-}$ concentrations from 1500 to $10 \mu \mathrm{M}$. Subsequent experiments with $\mathrm{NH}_{4}{ }^{+}$, urea ( $2 \mathrm{~N}$ atoms per urea molecule),

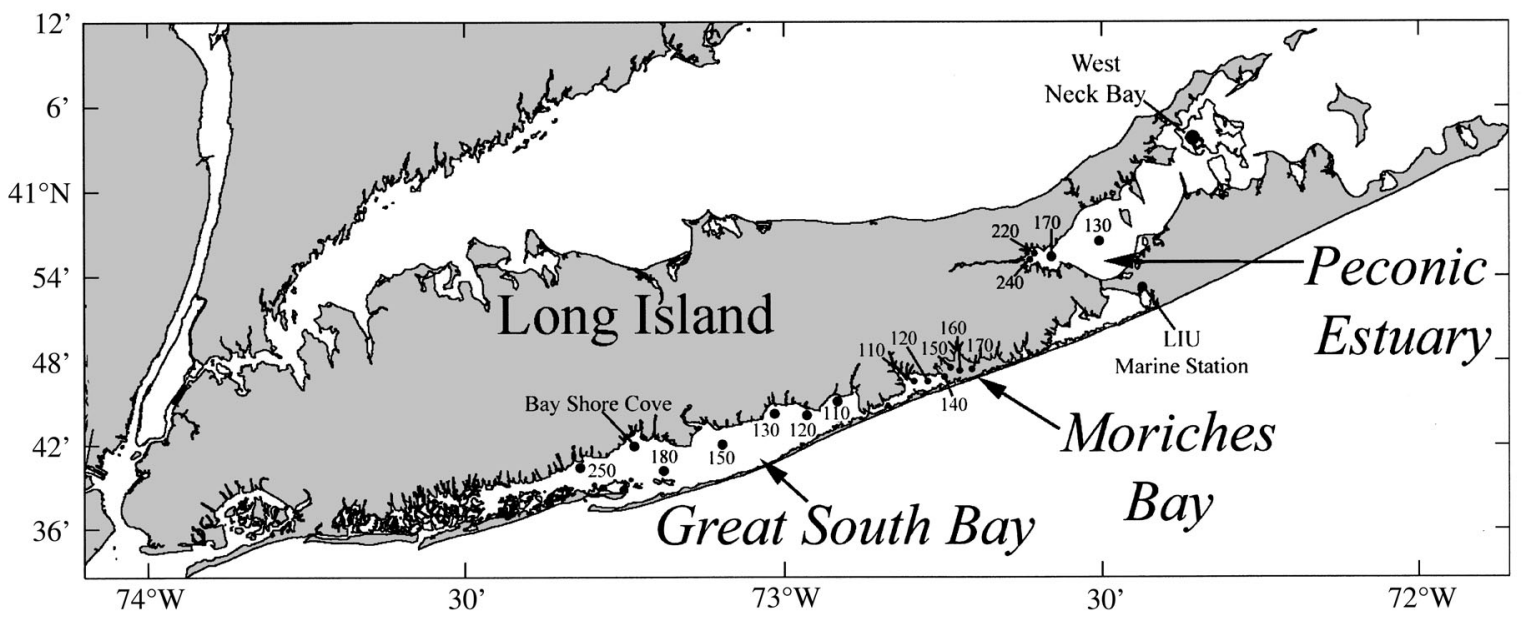

Fig. 1. Long Island embayments (New York, USA), including sampling sites for field validation experiment and Suffolk County Department of Health Services monitoring stations 
and glutamate utilized 6 diminishing nitrogen concentrations from 900 to $1 \mu \mathrm{M} \mathrm{N}$ for each algal species. To assure nutrient saturation, highest nitrogen concentrations were those of standard phycological media, exceeding ranges found in BT-prone and BT-free embayments by 10 to 100 -fold (Ryther \& Dunstan 1971, Carpenter \& Dunham 1985, Chang \& Carpenter 1985, Cosper et al. 1990, LaRoche et al. 1997, Gobler \& Sañudo-Wilhelmy 2001a, Gobler \& Boneillo 2003). Each set of flasks received a $1 \mathrm{ml}$ inoculum from a single microalgal culture, previously grown in $\mathrm{NO}_{3}{ }^{-}$ medium for $8 \mathrm{~d}$ (early stationary phase). This equated to final cell concentrations of $\sim 0.6$ to $3.4 \times 10^{5} \mathrm{ml}^{-1}$ or approximately 37 to $218 \mathrm{ng} \mathrm{N} \mathrm{ml}^{-1}$ of biomass at the experiment's initiation, depending on the species. During each experiment, samples were incubated under a fluorescent light bank, which was randomly arranged on a reflective white rotating platform (6 rpm) to cancel effects of spatial variations in illumination. Growth experiments were conducted under the same incubation conditions described above for maintenance cultures for $\sim 2 \mathrm{wk}$.

Accumulation of cell biomass through time was estimated by in vivo fluorescence, measured the same time each day to account for diel fluctuations in cell fluorescence. After gently swirling each culture, $3.5 \mathrm{ml}$ subsamples were removed from each flask and fluorescence was measured in a Turner Designs fluorometer. Previous research demonstrates that in vivo fluorescence is proportional to cell densities of a variety of cultured phytoplankton species (Fogg \& Thake 1987), including Aureococcus anophagefferens (Gobler \& Cosper 1996). Cellular chlorophyll a (chl a) content and consequently in vivo fluorescence obviously vary among species, and also vary within a species depending upon nitrogen source and physiological status (Carlsson et al. 1998). However, in vivo fluorescence is used here to generate biomass production rate constants $\left(\mathrm{d}^{-1}\right)$ under stable environmental conditions, so the actual chl a cell quotients are irrelevant to the calculation as long as they are relatively constant during early to mid-exponential growth phase.

Within-treatment reproducibility observed among triplicate flasks in these (Fig. 2a,b) and previous unreported bioassays was relatively high; mean relative standard deviation (SD mean ${ }^{-1}$ ) within treatments for $>800$ individual observations was $16 \%$ among all 5 algal species. Therefore, the practice of triplicating all treatments was discontinued because of limitations in incubator space and processing time.

At selected time points, subsamples were preserved in $2 \%$ buffered formaldehyde, then stained with DAPI and prepared for epifluorescent enumeration of algae and bacteria (Porter \& Feig 1980). Algal surveys were used to calibrate in vivo fluorescence measurements for each species and bacterial surveys used to assess contamination level. For elemental analysis, cells from each culture were harvested at mid-exponential phase, filtered onto precombusted GF/F filters, rinsed with filtered seawater, and stored frozen until analysis. Particulate organic carbon and nitrogen were analyzed on filters by combustion in a Carlo Erba EA1108 CHNS-O analyzer and corrected with filter and reagent blanks (Sharp 1991). Algal biomass estimates were also corrected for bacterial biomass contribution using DAPI counts and extrapolations of $149 \times 10^{-15} \mathrm{~g}$ $\mathrm{C}$ cell ${ }^{-1}$ and $35 \times 10^{-15} \mathrm{~g} \mathrm{~N}$ cell $^{-1}$ (Vrede et al. 2002).

Growth performance simulations. Growth curves were produced from daily in vivo fluorescence data. Growth rate, $\mu\left(\mathrm{d}^{-1}\right)$, was estimated from the slope of $\ln$ $\left(N_{t} / N_{0}\right)$ plotted against time, where $N_{0}$ and $N_{t}$ equal fluorescence unit accumulation, between times 0 and $t$. Regressions were based on 3 to 6 time points over which ln fluorescence increased linearly and most rapidly. The time interval employed varied between experiments, depending upon length of growth lags $(\leq 3 \mathrm{~d})$ and onset of nutrient exhaustion (stationary phase). All regressions were statistically significant $(\mathrm{p}<0.05)$ and typically yielded coefficients of determination $\left(\mathrm{r}^{2}\right)$ exceeding 0.90. Errors associated with determination of $\mu$ were represented by the standard error of the regression slope. Growth rates in most experiments were saturating functions of dissolved nitrogen concentration, $S\left(\mu=\mu_{\max }\left[S / K_{\mathrm{s}}+S\right]\right)$, permitting calculation of the Monod kinetic parameters $K_{\mathrm{s}}$ (half-saturation constant) and $\mu_{\max }$ (maximum growth rate). In 2 instances, an extended form of the Monod model $\left(\mu=\mu_{\max }\left[\left(S-S_{\min }\right) /\left(K_{\mathrm{s}}+S-S_{\min }\right]\right)\right.$ was employed because negative growth was observed below a finite nutrient concentration ( $S_{\min }$ Kovarova et al. 1996). Monod constants were estimated by 2 methods; indirectly by Eadee-Hofstee linear transformation and directly by iterative non-linear curve fitting (Marquardt-Levenberg method: SPSS SigmaPlot version 8.0). As evaluated in Berges et al. (1994), non-linear curve fitting is more appropriate for geometrically distributed data and this technique systematically yielded higher coefficients of determination $\left(\mathrm{r}^{2}\right)$ than linear transforms in our study. Therefore, only Monod constants derived from non-linear curve fitting are reported.

Growth performance simulations incorporated lag periods and Monod constants $\left(\mu_{\max }, K_{\mathrm{s}}, S_{\min }\right)$ and assumed an arbitrary initial condition of equivalent biomasses for all 5 species tested $\left(N_{0}=0.1 \mathrm{ng} \mathrm{N} \mathrm{ml}^{-1}\right)$, representing an early spring field condition of 60 to 300 cells $\mathrm{ml}^{-1}$, depending on species. To predict how a fixed nutrient concentration determines relative abundances of the 5 species through time within a simplified phytoplankton community, concentration- 
dependent growth rates $\left(\mu=\mu_{\max }\left[\left(S-S_{\min }\right) /\left(K_{\mathrm{s}}+S-\right.\right.\right.$ $\left.\left.S_{\min }\right)\right]$ ) were applied to the logistic growth equation $\left(N_{t}\right.$ $=N_{0} \mathrm{e}^{\mu t}$ ) for each species, where $N_{t}$ equals biomass at time $t$. As long as a lag period (l) was apparent, $N_{t}$ was assumed to equal $N_{0}$ : i.e. if $(t-l) \leq 0$, then $N_{t}=N_{0}$. Simulations were run for $7 \mathrm{~d}$ because rank order of biomass production among species did not change beyond that time, although relative abundances did. Our model assumed no removal and that nutrient supply kept pace with plankton uptake, resulting in steady-state nutrient concentrations for the duration of the simulation.

Field experiment. Variations in groundwater flow and porewater seepage alter nutrient chemistry in Long Island bays and are believed to influence brown tide blooms (LaRoche et al. 1997, Gobler \& SañudoWilhelmy 2001b, Lomas et al. 2004). Therefore, growth of Aureococcus anophagefferens within natural phytoplankton assemblages was examined in baywater amended either with local groundwater or benthic porewater. Subtidal groundwater was collected from an intertidal piezometer on the shoreline of a bloomprone embayment, West Neck Bay (Fig. 1) then filtered and stored frozen (see Gobler \& Sañudo-Wilhelmy $2001 \mathrm{~b}$ for procedures). Benthic porewater was isolated from subtidal surface sediments $(0$ to $20 \mathrm{~cm})$ collected from western Great South Bay via centrifugation at $1990 \times g$ (Aller \& Benninger 1981). Immediately following centrifugation, benthic porewater was filtered $(0.2 \mu \mathrm{m})$ and stored frozen. Nitrate, nitrite, ammonium, phosphate, and total dissolved nitrogen (TDN) content of all water samples were determined by standard spectrophotometric techniques (Valderrama 1981, Jones 1984, Parsons et al. 1984). DON was calculated as the difference between TDN and dissolved inorganic nitrogen (nitrate, nitrite, and ammonium).

Baywater was collected in $\mathrm{HCl}$-cleaned polycarbonate bottles on 24 June 2001 from Bay Shore Cove, in western Great South Bay (Fig. 1) during a brown tide bloom ( $>10^{5}$ Aureococcus anophagefferens $\mathrm{ml}^{-1}$ ). The experiment was initiated by amending triplicate flasks with groundwater or benthic porewater to achieve final TDN (DIN + DON) additions of $7.5 \mu \mathrm{M} \mathrm{N}$ in all flasks. To ensure volumes and salinities remained constant among all treatments, control and porewateramended flasks received an equivalent volume of Milli-Q water, and groundwater-amended flasks received additions of $0.2 \mu \mathrm{m}$-filtered, aged seawater from Bay Shore Cove. Freshwater additions decreased final salinity from $\sim 27$ to $\sim 25 \mathrm{psu}$, remaining within the physiological optimum for $A$. anophagefferens (Cosper et al. 1989a). The $7.5 \mu \mathrm{M}$ TDN porewater and groundwater amendments were repeated at 24,48 , and $72 \mathrm{~h}$ to maintain nutrient inventories semi-continuously. Amended TDN concentrations and final salinities were similar to those previously observed in the water column of BT prone-embayments on Long Island (LaRoche et al. 1997). Incubations were conducted by immersing flasks in Old Fort Pond at the Southampton College (Long Island University [LIU]) Marine Station (Fig. 1), closely mimicking ambient light and temperature conditions found in Great South Bay (Gobler et al. 2002).

At $0,24,48$ and $72 \mathrm{~h}$, subsamples from all flasks were filtered through GF/F glass fiber filters for chl a determinations using standard fluorometric techniques (Parsons et al. 1984). At 72 h, $10 \mathrm{ml}$ aliquots were preserved with $1 \%$ glutaraldehyde (final conc.) and stored at $5{ }^{\circ} \mathrm{C}$ for enumeration of algal cell densities. Cyanobacteria were enumerated by autofluorescent microscopy on slides prepared within $24 \mathrm{~h}$ of preservation and stored frozen until analysis (MacIsaac \& Stockner 1993). Aureococcus anophagefferens densities were enumerated by the immunofluorescent direct count method from the preserved samples (Anderson et al. 1989).

\section{RESULTS}

\section{Response of Aureococcus anophagefferens to inorganic $\mathrm{N}$-speciation}

The growth rate of Aureococcus anophagefferens was stimulated by increasing $\mathrm{NO}_{3}{ }^{-}$concentrations up to $200 \mu \mathrm{M}$, but not at higher concentrations (Fig. 2a). During exponential growth phase, initial slopes for 200, 500, 900 and $1500 \mu \mathrm{M} \mathrm{NO}_{3}{ }^{-}$curves were not significantly different from one another $(p>0.05$; ANCOVA), suggesting saturating growth rates at these concentrations. The medium's initial o- $\mathrm{PO}_{4}{ }^{3-}$ concentration was $36 \mu \mathrm{M}$, so that N:P ratios surpassed 16 at $570 \mu \mathrm{M}$. Hence cell yields in the highest nitrate exposures were similar, and were probably limited by final o- $\mathrm{PO}_{4}{ }^{3-}$ availability. P-limitation may have been operative for all algal species tested at high $\mathrm{N}$ concentrations, regardless of chemical form. Cultures reached stationary phase after $4 \mathrm{~d}$ at the lowest concentration and $7 \mathrm{~d}$ at the highest, illustrating the time required to exhaust useable $\mathrm{NO}_{3}{ }^{-}$and reach nutrient limitation, whether limited by $\mathrm{N}$ or $\mathrm{P}$.

Growth response of Aureococcus anophagefferens to increasing concentrations of $\mathrm{NH}_{4}{ }^{+}$was markedly different to its response to $\mathrm{NO}_{3}{ }^{-}$(Fig. 2b). At the lowest concentrations, 1 and $10 \mu \mathrm{M}$, cultures grew immediately and reached stationary phase within $5 \mathrm{~d}$. At $50 \mu \mathrm{M}$, in vivo fluorescence measurements at Days 0 and 3 were equivalent, suggesting that $A$. anophagefferens growth lagged after transfer from $\mathrm{NO}_{3}{ }^{-}$ medium. Exponential phase was then sustained for $3 \mathrm{~d}$ 

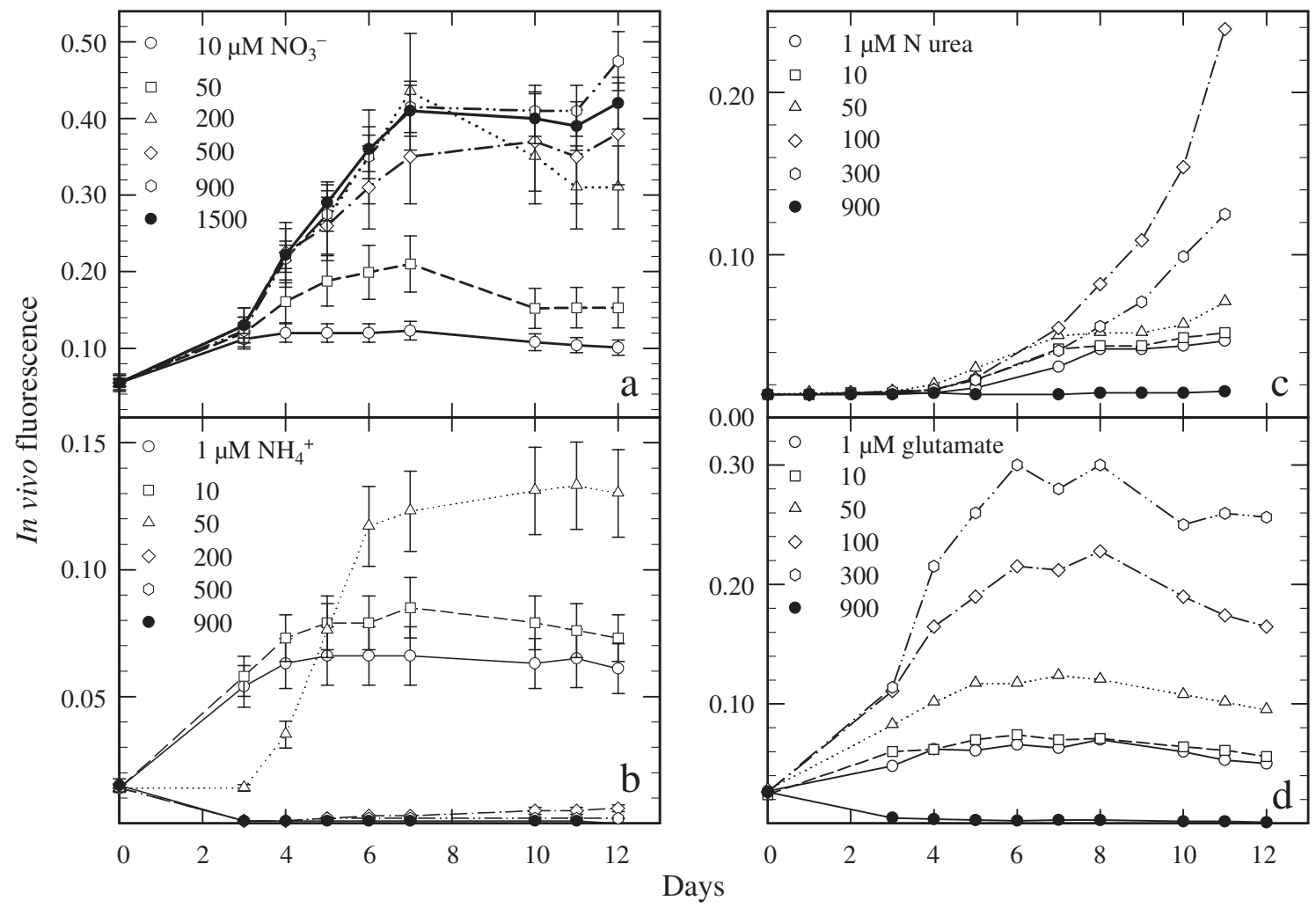

Fig. 2. Aureococcus anophagefferens. Growth curves under a range of concentrations of (a) nitrate, (b) ammonium, (c) urea or (d) glutamate as primary N sources in standard BT medium. Samples incubated on a 14:10 h light:dark cycle. Cell biomass determined using proxy of in vivo fluorescence. $(\mathrm{a}, \mathrm{b})$ Error bars in represent $1 \mathrm{SD}$ from triplicate incubation flasks. Analytical precision of in vivo fluorescence measurements was $\pm 1.4 \%$ relative $\mathrm{SD}$, so errors were smaller than symbols

before reaching stationary phase. Exposures of $A$. anophagefferens to $\mathrm{NH}_{4}^{+}$concentrations $\geq 200 \mu \mathrm{M}$ appeared to be strongly inhibitory, if not lethal (see lower 3 curves, Fig. 2b).

Transfer from $\mathrm{NO}_{3}{ }^{-}$to urea-based media delayed initiation of detectable growth in cultures of Aureococcus anophagefferens by 2 to $3 \mathrm{~d}$ at all concentrations (1 to $900 \mu \mathrm{M} \mathrm{N}$ ) (Fig. 2c). Growth lags observed in all treatments of this experiment and in some treatments of other experiments revealed that carry-over of residual $\mathrm{NO}_{3}{ }^{-}$with the original inoculum was insufficient to support detectable growth. Lags also demonstrated that acclimation of cultures was sometimes necessary for growth after transfer to a new nitrogen source. Similar to ammonium, rates of $A$. anophagefferens accumulation increased over the lower range in urea concentrations $(\leq 100 \mu \mathrm{M} N)$, decreased at $300 \mu \mathrm{M} \mathrm{N}$, and were essentially zero at $900 \mu \mathrm{M}$ N.

Cultures transferred to media with the amino acid glutamate as the sole source of nitrogen appeared to grow almost immediately (Fig. 2d). In contrast to results from other reduced forms of $\mathrm{N}$, cultures responded positively to increasing glutamate concentrations up to $300 \mu \mathrm{M} \mathrm{N}$. However, exposures to
$900 \mu \mathrm{M} N$ of glutamate appeared to be lethal, as was also observed for ammonium and urea (but not nitrate).

\section{Growth rate comparisons}

Growth curves similar to those presented in Fig. 2 were simultaneously generated for the other 4 algal species (not presented), allowing calculation of specific growth rates of all species at each nutrient concentration. Analysis of growth rates for all species illustrated that when $\mathrm{NO}_{3}{ }^{-}$was the predominant nitrogenous nutrient available, Aureococcus anophagefferens was only capable of relatively meager growth rates, 0.17 to 0.30 doublings $\mathrm{d}^{-1}$ (simply ' $\mathrm{d}^{-1}$ ' hereafter), even after being maintained in nitrate-based media for many generations (Fig. 3a). Aureococcus anophagefferens grew slower on $\mathrm{NO}_{3}^{-}\left(\mu_{\max }=0.30 \mathrm{~d}^{-1}\right)$ and had a higher half saturation constant $\left(K_{\mathrm{s}}=8.6 \mu \mathrm{M}\right)$ than any other microalga tested, independent of nutrient concentration (Table 1). In sharp contrast, nitrate-fed Thalassiosira pseudonana cultures outgrew all species tested, followed by Nannochloris atomus. Growth rates of Synechococcus bacillaris and Prorocentrum minimum 

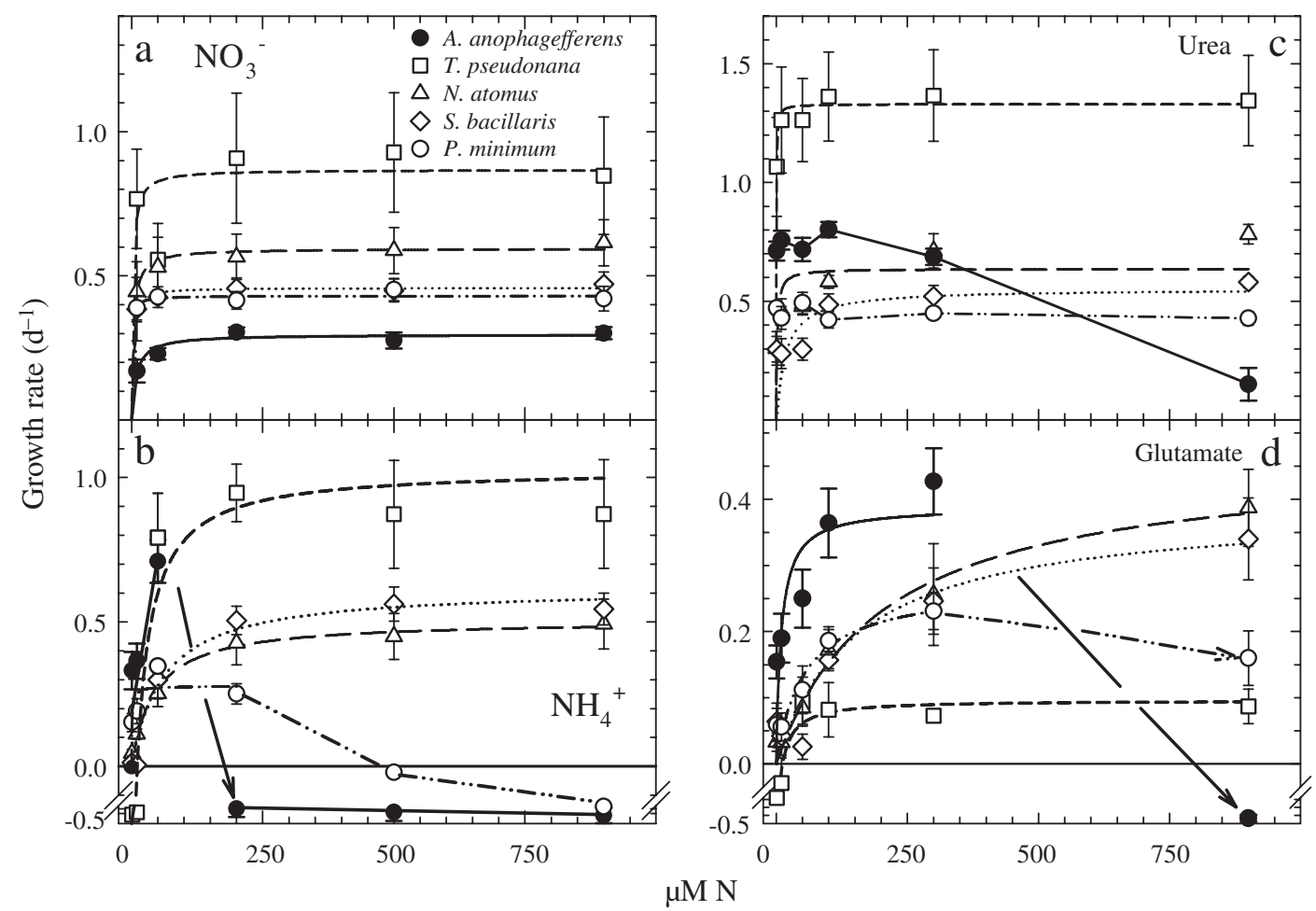

Fig. 3. Growth rates for 5 species under ranges of (a) nitrate, (b) ammonium, (c) urea, or (d) glutamate. Symbols represent slope of $\ln \left[N_{t} / N_{0}\right]$ versus $t$ in growth curves; error bars are SE of regression slopes

were similar over the entire $\mathrm{NO}_{3}{ }^{-}$concentration range tested. Even though T. pseudonana possessed the highest $\mu_{\max }\left(0.87 \mathrm{~d}^{-1}\right)$, its $K_{\mathrm{s}}$ for $\mathrm{NO}_{3}^{-}(2.5 \mu \mathrm{M})$ was slightly higher than those of $S$. bacillaris and P. minimum (Table 1). Use of an approximation of the Monod equation's slope $\left(\mu_{\max } / K_{\mathrm{s}}\right)$ as an index of competitive advantage (Healey 1980) clearly demonstrated that $A$. anophagefferens is a poor competitor for $\mathrm{NO}_{3}{ }^{-}$; the $\mu_{\max } / K_{\mathrm{s}}$ ratio for $A$. anophagefferens was 5 - to 10 -fold lower than for other species (Table 1). For all species, growth rates approached their maxima at $\mathrm{NO}_{3}^{-}$concentrations between 50 and $200 \mu \mathrm{M}$ N. In this concentration range, $\mathrm{P}$ limitation on growth is unlikely for any species (see above), but $\mathrm{Si}$ availability may have limited $T$. pseudonana yields at higher $\mathrm{NO}_{3}^{-}$concentrations; silicic acid in the media was $110 \mu \mathrm{M}$, and while the stoichiometry of $\mathrm{Si}: \mathrm{N}$ can vary among diatom species, a 1:1 stoichiometry is generally assumed (Brzezinski 1985).

In $\mathrm{NH}_{4}{ }^{+}$-fed cultures, our microalgal populations responded very differently (Fig. 3b). At $\mathrm{NH}_{4}{ }^{+}$concentrations below $50 \mu \mathrm{M}$, Aureococcus anophagefferens was capable of growth rates $( \pm \mathrm{SE})$ of about $0.35 \pm$ $0.06 \mathrm{~d}^{-1}$; growth rates among other species varied from negative at $S_{\text {min }}$ below $13 \mu \mathrm{M}$ (Thalassiosira pseudonana) to $0.19 \pm 0.04 \mathrm{~d}^{-1}$ (Prorocentrum minimum). At $50 \mu \mathrm{M}$, A. anophagefferens and T. pseudo- nana grew at least twice as fast as other species and achieved comparable growth rates $\left(0.71\right.$ to $\left.0.79 \mathrm{~d}^{-1}\right)$, but both species exhibited growth lags of $\leq 3 \mathrm{~d}$ when acclimating to high concentrations of $\mathrm{NH}_{4}{ }^{+}$after being in $\mathrm{NO}_{3}{ }^{-}$maintenance cultures. Over the remaining concentration range, T. pseudonana achieved higher growth rates than all other species; however, the $3 \mathrm{~d}$ lag phase was still present at all concentrations. Nannochloris atomus and Synechococcus bacillaris were similarly stimulated by increasing ammonium concentrations, and exhibited comparable growth rates except at the lowest concentrations. Similar to $\mathrm{NO}_{3}{ }^{-}$ trials, maximum growth rates were approached at $\mathrm{NH}_{4}{ }^{+}$concentrations above $100 \mu \mathrm{M}$ for T. pseudonana, $N$. atomus, and $S$. bacillaris. In contrast to $\mathrm{NO}_{3}{ }^{-}$ trials, inhibitory effects of $\mathrm{NH}_{4}{ }^{+}$were evident at concentrations above $50 \mu \mathrm{M}$ for $A$. anophagefferens, and at concentrations above $200 \mu \mathrm{M}$ for P. minimum; populations experienced die off after being transferred from $\mathrm{NO}_{3}^{-}$maintenance cultures to media containing high concentrations of $\mathrm{NH}_{4}^{+}$. These 2 species appeared to be most competitive at low $\mathrm{NH}_{4}{ }^{+}$concentrations, $\mu_{\max } / K_{\mathrm{s}} \geq 0.1$ and 0.3 , respectively, but exact determination of the kinetics constants was difficult given the existing data (Fig. 3b; Table 1).

Urea supported superior growth rates (1.1 to $\left.1.4 \mathrm{~d}^{-1}\right)$ of Thalassiosira pseudonana at all concentrations 
Table 1. Monod kinetic parameters for all species and nutrients estimated by iterative, non-linear curve-fitting to the formula $\mu=\mu_{\max }\left[\left(S-S_{\min }\right)\left(K_{\mathrm{s}}+S-S_{\min }\right)^{-1}\right]$. Standard errors in parentheses. $\mathrm{r}^{2}=$ coefficient of determination or curve's goodness of fit to data; lag $=$ time interval over which chl a remained constant for all concentrations. Values in bold indicate principal kinetic parameters in determining population response

\begin{tabular}{|c|c|c|c|c|c|}
\hline Variable & $\begin{array}{c}\text { Aureococcus } \\
\text { anophagefferens }\end{array}$ & $\begin{array}{l}\text { Thalassiosira } \\
\text { pseudonana }\end{array}$ & $\begin{array}{c}\text { Nannochloris } \\
\text { atomus }\end{array}$ & $\begin{array}{c}\text { Synechococcus } \\
\text { bacillaris }\end{array}$ & $\begin{array}{l}\text { Prorocentrum } \\
\text { minimum }\end{array}$ \\
\hline \multicolumn{6}{|l|}{$\mathrm{NO}_{3}^{-}$} \\
\hline$K_{\mathrm{s}}(\mu \mathrm{M} \mathrm{N})$ & $8.6(2.0)$ & $2.5(2.8)$ & $3.7(0.6)$ & $2.1(0.3)$ & $1.1(0.4)$ \\
\hline$\mu_{\max }\left(d^{-1}\right)$ & $0.30(0.01)$ & $0.87(0.07)$ & $0.59(0.01)$ & $0.46(0.01)$ & $0.43(0.01)$ \\
\hline$\mu_{\max } / K_{\mathrm{s}}$ & 0.04 & 0.40 & 0.20 & 0.20 & 0.40 \\
\hline $\mathrm{r}^{2}$ & 0.98 & 0.86 & 0.99 & 0.99 & 0.99 \\
\hline $\operatorname{Lag}(d)$ & 0 & 0 & 0 & 0 & 0 \\
\hline \multicolumn{6}{|l|}{$\mathrm{NH}_{4}{ }^{+}$} \\
\hline$K_{\mathrm{s}}(\mu \mathrm{M} \mathrm{N})$ & $6.4^{\mathrm{a}}$ & $34(21)^{\mathrm{b}}$ & $44(7.3)$ & $61(21)$ & $0.7(0.4)$ \\
\hline$\mu_{\max }\left(\mathrm{d}^{-1}\right)$ & $0.71^{a}$ & $1.02(0.13)$ & $0.51(0.02)$ & $0.62(0.05)$ & $0.23(0.02)$ \\
\hline$\mu_{\max } / K_{\mathrm{s}}$ & 0.10 & 0.03 & 0.01 & 0.01 & 0.30 \\
\hline $\mathrm{r}^{2}$ & 0.99 & 0.91 & 0.99 & 0.97 & 0.97 \\
\hline $\operatorname{Lag}(\mathrm{d})$ & $0-3$ & 3 & 0 & 0 & 0 \\
\hline \multicolumn{6}{|l|}{ Urea } \\
\hline$K_{\mathrm{s}}(\mu \mathrm{M} \mathrm{N})$ & $<0.4^{\mathrm{c}}$ & $0.3(0.06)$ & $2.2(1.5)$ & $18(9.2)$ & $<0.5^{\mathrm{c}}$ \\
\hline$\mu_{\max }\left(d^{-1}\right)$ & $0.75^{\mathrm{d}}$ & $1.33(0.02)$ & $0.64(0.06)$ & $0.55(0.05)$ & $0.45^{\mathrm{d}}$ \\
\hline$\mu_{\max } / K_{\mathrm{s}}$ & 1.90 & 4.40 & 0.30 & 0.03 & 0.90 \\
\hline $\mathrm{r}^{2}$ & - & 0.99 & 0.86 & 0.91 & - \\
\hline $\operatorname{Lag}(\mathrm{d})$ & 1 & 0 & 0 & 1 & 3 \\
\hline \multicolumn{6}{|l|}{ Glutamate } \\
\hline$K_{\mathrm{s}}(\mu \mathrm{M})$ & $9.8(8.4)$ & $22(19)^{b}$ & $203(44)$ & $151(70)$ & $53(31)$ \\
\hline$\mu_{\max }\left(d^{-1}\right)$ & $0.39(0.06)$ & $0.10(0.02)$ & $0.46(0.04)$ & $0.39(0.06)$ & $0.27(0.05)$ \\
\hline$\mu_{\max } / K_{\mathrm{s}}$ & 0.040 & 0.005 & 0.002 & 0.003 & 0.005 \\
\hline $\mathrm{r}^{2}$ & 0.81 & 0.95 & 0.98 & $0.95^{\mathrm{e}}$ & $0.91^{\mathrm{e}}$ \\
\hline $\operatorname{Lag}(\mathrm{d})$ & 0 & 0 & 3 & 3 & 0 \\
\hline
\end{tabular}

(Fig. 3c). At urea concentrations of $50 \mu \mathrm{M}(100 \mu \mathrm{M} N)$ or less, Aureococcus anophagefferens achieved the second highest growth rates, 0.69 to $0.80 \mathrm{~d}^{-1}$, but growth performance diminished at higher urea concentrations. In fact, $A$. anophagefferens was the only microalga to experience inhibition at high urea concentrations. Growth rates of Nannochloris atomus and Synechococcus bacillaris exhibited Monod kinetics over the urea concentration range examined (Fig. 3c). In contrast, Prorocentrum minimum's growth rates ( 0.42 to $\left.0.49 \mathrm{~d}^{-1}\right)$ appeared to be independent of the urea concentrations employed ( $p>0.05)$, which suggested nutrient saturation near $1 \mu \mathrm{M} N$ urea. Lags in growth were evident for $A$. anophagefferens ( $\leq 1 \mathrm{~d}), S$. bacillaris $(\leq 1 \mathrm{~d})$, and $P$. minimum $(\leq 3 \mathrm{~d})$, which suggested acclimation to a new $\mathrm{N}$ source in these cultures that was not apparent for T. pseudonana nor N. atomus. Estimates of $\mu_{\max }$ were highest on a urea diet for all species except $S$. bacillaris (Table 1). Competitive performance $\left(\mu_{\max } / K_{\mathrm{s}}\right)$ for urea appeared to be highest in T. pseudonana, A. anophagefferens, and $P$. minimum, although accurate $K_{\mathrm{s}}$ determinations for the last
2 species were not possible because sub-micromolar concentrations were not tested (Table 1).

Glutamate favored growth of Aureococcus anophagefferens over the other 4 microalgae at all concentrations below $900 \mu \mathrm{M} N$ (Fig. 3d). From 1 to $300 \mu \mathrm{M}$, growth rates of $A$. anophagefferens followed Monod kinetics, and exhibited modest maximal growth and half-saturation constants: $\mu_{\max }=0.39 \mathrm{~d}^{-1}$ and $K_{\mathrm{s}}=$ $9.8 \mu \mathrm{M}$ (Table 1). However, growth rates of $A$. anophagefferens were negative at the highest glutamate concentration. Similar to $\mathrm{NH}_{4}{ }^{+}$, only glutamate concentrations above $12 \mu \mathrm{MN}\left(S_{\min }\right)$ supported growth of Thalassiosira pseudonana, and then only slowly at best $\left(<0.10 \pm 0.03 \mathrm{~d}^{-1}\right)$. Nannochloris atomus and Synechococcus bacillaris responded similarly to glutamate as a primary $\mathrm{N}$ source, yielding $\mu_{\max }$ of 0.46 and $0.39 \mathrm{~d}^{-1}$ and high $K_{\mathrm{s}}$ values of 203 and $151 \mu \mathrm{M} \mathrm{N}$, respectively (Table 1). Both species exhibited delays in growth of $\leq 3 \mathrm{~d}$ when glutamate was the primary nitrogen source. Growth rates of Prorocentrum minimum were not detectably different between 1 and $10 \mu \mathrm{M} \mathrm{N}$ $\left(0.06 \mathrm{~d}^{-1}\right)$, but did increase hyperbolically $\left(\mathrm{r}^{2}=0.91\right)$ 
between 10 and $300 \mu \mathrm{M} \mathrm{N}$, attaining a $\mu_{\max }$ of only $0.27 \mathrm{~d}^{-1}$ (Table 1). Like A. anophagefferens, growth of $P$. minimum was inhibited at the highest glutamate concentration.

\section{Growth performance simulations}

Growth performance simulations were run to predict which algal species would dominate a hypothetical phytoplankton community in a nitrogen-limited system after nitrogen speciation shifted from nitratedomination, as it might seasonally in coastal embayments. Simulations incorporated Monod kinetics estimates (Table 1), lag periods, and threshold concen-

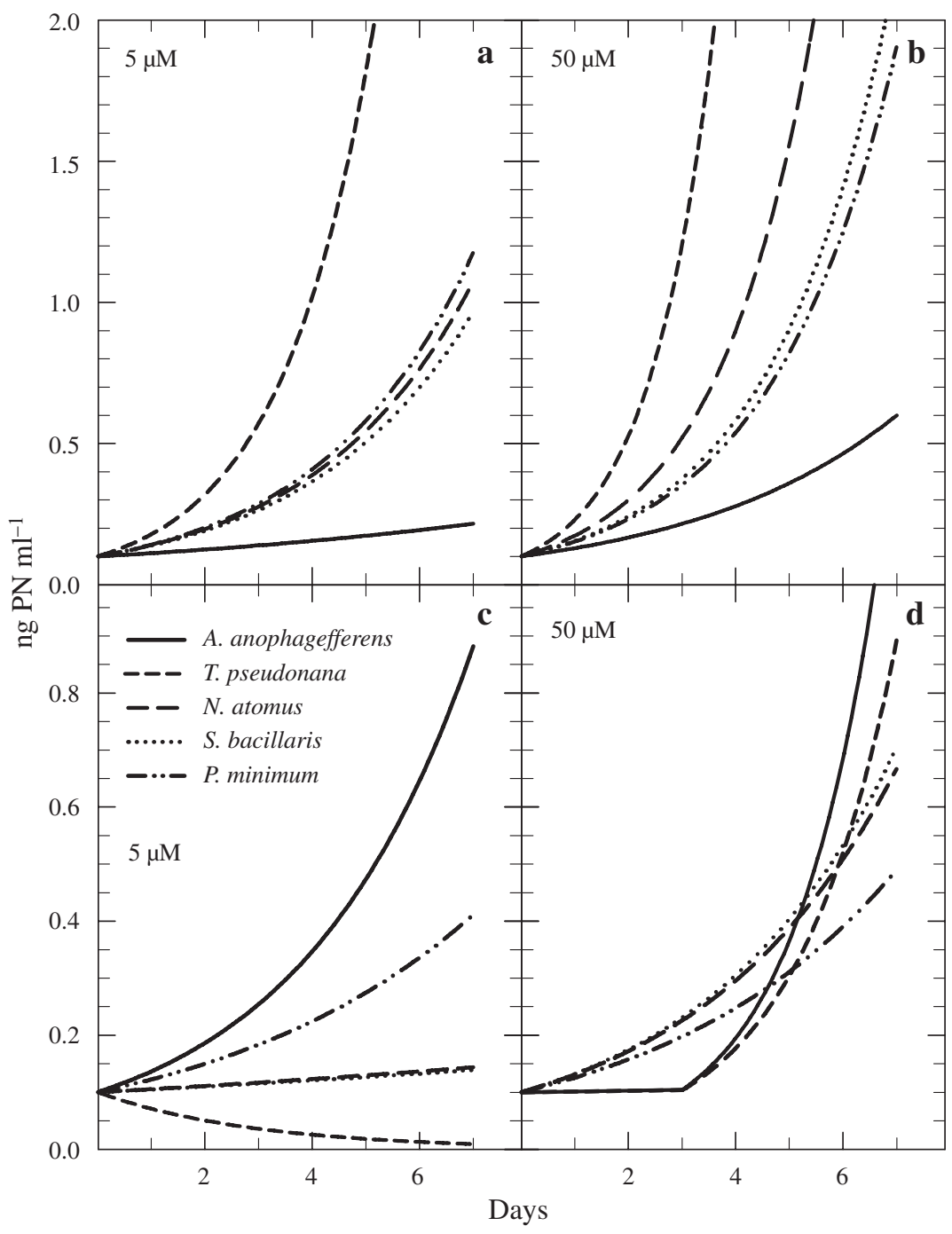

Fig. 4. Examples of growth performance simulations, expressed as particulate nitrogen (PN) for 5 species offered (a) 5 or (b) $50 \mu \mathrm{M} \mathrm{NO}_{3}{ }^{-}$, and (c) 5 or (d) $50 \mu \mathrm{M}$ $\mathrm{NH}_{4}{ }^{+}$. Model assumed biomass of each species was $0.1 \mathrm{ng} \mathrm{N} \mathrm{ml}{ }^{-1}$ at Day 0 , nitrogen was the only growth-limiting nutrient, and its concentration remained constant. Growth rates and lag times applied to the logistic equation trations to generate growth curves for each species at a specific nutrient concentration. Simulations assumed an initial state of low but equivalent biomass and constant nutrient supply, examples of which are presented in Fig. 4. Outcomes of modeled growth were similar at $\mathrm{NO}_{3}^{-}$concentrations of 5 and $50 \mu \mathrm{M}$; Thalassiosira pseudonana would rapidly outgrow the other 4 species and Aureococcus anophagefferens would be the slowest grower (Fig. 4a,b). At $50 \mu \mathrm{M} \mathrm{NO}_{3}{ }^{-}$, Nannochloris atomus appeared to have a slight competitive advantage over Synechococcus bacillaris and Prorocentrum minimum that was not apparent at $5 \mu \mathrm{M} \mathrm{NO}_{3}^{-}$ (Fig. 4a,b).

In the absence of other N-sources, low concentrations of $\mathrm{NH}_{4}{ }^{+}(5 \mu \mathrm{M})$ clearly favored a community dominated by Aureococcus anophagefferens, distantly followed by $P$. minimum (Fig. 4c). After $7 \mathrm{~d}$, the other 3 species would be rare. At higher $\mathrm{NH}_{4}{ }^{+}$concentrations $(\geq 50 \mu \mathrm{M})$, selective advantage initially favored Synechococcus bacillaris, Nannochloris atomus, and Prorocentrum minimum. However, A. anophagefferens and Thalassiosira pseudonana may gain dominance after a growth lag, if other factors do not become limiting (Fig. 4a).

Rank order outcomes of all simulation runs were tabulated as ratios of biomass yields after $1 \mathrm{wk}$, and normalized to the least abundant species in that trial. Results for low, intermediate, and high concentrations are summarized in Table 2 to represent general trends along trophic gradients. Results for $\mathrm{NO}_{3}{ }^{-}$were the most straightforward and consistent. At all concentrations tested, Thalassiosira pseudonana dominated this simulated phytoplankton community, outweighing Aureococcus anophagefferens by 5- to 55fold and the other species by at least 1.7 - to 7 -fold (Table 2).

Results for $\mathrm{NH}_{4}{ }^{+}$simulations were more varied (Table 2). At $1 \mu \mathrm{M}$, Prorocentrum minimum was a slightly better competitor than Aureococcus anophagefferens and growth of both species far outpaced the other 3 species. At $10 \mu \mathrm{M}, A$. anophagefferens and $P$. minimum biomasses were highest after $7 \mathrm{~d}$, with $A$. anophagefferens $>$ 40-fold more abundant than Thalassiosira pseudonana, the poorest performer under these conditions. At 
Table 2. Results from simulations of 5 microalgal species competing for nitrogen available in varying forms and concentrations. Model outcome based on equal initial cell biomass (0.1 ng particulate nitrogen $\mathrm{ml}^{-1}$ ), constant nutrient supply, predicted growth rates $\left(\mu \mathrm{d}^{-1}\right)$ and observed lag periods (0 to $3 \mathrm{~d}$ ). Reported in descending rank order as relative cell yields, normalized to the species with the lowest yield at the end of a $1 \mathrm{wk}$ incubation under constant environmental conditions. $\mathrm{A}=$ Aureococcus anophagefferens; $\mathrm{N}=$ Nannochloris atomus; $\mathrm{P}=$ Prorocentrum minimum $; \mathrm{S}=$ Synechococcus bacillaris $; \mathrm{T}=$ Thalassosira pseudonana

\begin{tabular}{|ll|}
\hline Nitrogen species & Relative yields after $7 \mathrm{~d}$ \\
\hline $\mathrm{NO}_{3}^{-}$ & \\
$1 \mu \mathrm{M}$ & 5T:3P:2S:2N:1A \\
$10 \mu \mathrm{M}$ & 42T:7N:5P:5S:1A \\
$50 \mu \mathrm{M}$ & 55T:8N:4S:3P:1A \\
$\mathbf{N H}_{4}^{+}$ & \\
$1 \mu \mathrm{M}$ & 205P:156A:86N:85S:1T \\
$10 \mu \mathrm{M}$ & 44A:10P:4N:4S:1T \\
$50 \mu \mathrm{M}$ & 3A:2T:1S:1N:1P \\
Urea & \\
$1 \mu \mathrm{M} \mathrm{N}$ & 1083T:21A:5P:3N:1S \\
$10 \mu \mathrm{M}$ & $2592 \mathrm{~T}: 23 \mathrm{~A}: 12 \mathrm{~N}: 2 \mathrm{P}: 1 \mathrm{~S}$ \\
$50 \mu \mathrm{M}$ & 1472T:12A:10N:2S:1P \\
Glutamate & \\
$1 \mu \mathrm{M}$ & $3 \mathrm{~A}: 2 \mathrm{P}: 2 \mathrm{~S}: 2 \mathrm{~N}: 1 \mathrm{~T}$ \\
$10 \mu \mathrm{M}$ & $4 \mathrm{~A}: 1 \mathrm{P}: 1 \mathrm{~S}: 1 \mathrm{~N}: 1 \mathrm{~T}$ \\
$50 \mu \mathrm{M}$ & 7A:2P:1T:1S:1N \\
\hline
\end{tabular}

higher $\mathrm{NH}_{4}{ }^{+}$concentrations $(50 \mu \mathrm{M})$, T. pseudonana became more common, but competitive advantage for any single species eroded. Despite T. pseudonana's delayed growth when exposed to $\mathrm{NH}_{4}{ }^{+}$(3 d lag), its unresponsiveness to low $\mathrm{NH}_{4}{ }^{+}$concentrations $\left(S_{\min }=\right.$ $13 \mu \mathrm{M})$ and its relatively weak functional response $\left(\mu_{\max } / K_{\mathrm{s}}=0.03\right)$, its high $\mu_{\max }$ allowed it to outgrow all but $A$. anophagefferens within the $1 \mathrm{wk}$ simulation (Fig. 4d, Tables 1 \& 2).

Over the entire simulated range in urea concentrations (1 to $50 \mu \mathrm{M} \mathrm{N}$ ), the hypothetical community would be dominated by Thalassiosira pseudonana and Aureococcus anophagefferens, but T. pseudonana was favored 50- to 110-fold over the BT organism after $1 \mathrm{wk}$ (Table 2). The combination of weak functional response for urea $\left(\mu_{\max } / K_{\mathrm{s}}=0.03\right)$, modest growth rate, and $1 \mathrm{~d}$ lag in growth when exposed to urea placed Synechococcus bacillaris at a competitive disadvantage at all urea concentrations. Simulations suggested that relative abundances of Nannochloris atomus would increase with urea concentrations, displacing Prorocentrum minimum as third most abundant species.

Glutamate conferred a clear competitive advantage to Aureococcus anophagefferens over the other 4 species, consistently fol- lowed by Prorocentrum minimum at all concentrations (Table 2, Fig. 3d). However, biomass yields for $A$. anophagefferens after 1 wk were low compared to yields from $\mathrm{NH}_{4}{ }^{+}$or urea, because only a moderate $\mu_{\max }$ was achieved $\left(0.39 \mathrm{~d}^{-1}\right)$ on a glutamate diet (Table $1)$. While its functional response $\left(\mu_{\max } / K_{\mathrm{s}}\right)$ was an order of magnitude more sensitive to changes in glutamate concentration than those of other algae, A. anophagefferens' competitive advantage appeared to be modest as evidenced by small biomass ratios apparent at low and intermediate glutamate concentrations compared to other nutrients (Table 2). While Nannochloris atomus and Synechococcus bacillaris' growth potentials were among the 3 highest (Table 1), their growth lags and low $\mu_{\max } / K_{\mathrm{s}}$ ratios prevented them from effectively competing for resources.

\section{Natural assemblages}

Results from our growth experiments and simulations strongly supported the hypothesis that nitrogen speciation can exert selective pressure on phytoplankton species in Long Island embayments. Nitrogen speciation in the source waters of these shallow bays may be strongly influenced by the residence time of subtidal groundwater passing through sediments. In fact, the porewater and groundwater we isolated from coastal Long Island has similar TDN levels, but very different N-speciation (Table 3). In our groundwater sample, $97 \%$ of the dissolved $\mathrm{N}$ was $\mathrm{NO}_{3}{ }^{-}(320 \mu \mathrm{M})$ and most of the remaining $3 \%$ was DON (Table 3 ). In contrast, benthic porewater was depleted in $\mathrm{NO}_{3}{ }^{-}$and enriched in $\mathrm{NH}_{4}^{+}(130 \mu \mathrm{M} ; 56 \%$ of TDN) and DON (100 $\mu \mathrm{M} ; 43 \%$ of TDN) (Table 3$)$. Nitrogen inventories in Great South Bay during a brown tide outbreak were clearly dominated by DON, which comprised $89 \%$ of TDN (Table 3).

Amending seawater from western Great South Bay with groundwater and porewater had a clear impact on the BT-dominated algal community. Control treatments exhibited a steady decrease in chl a from 16 to $10 \mu \mathrm{g} \mathrm{l}^{-1}$ during the $72 \mathrm{~h}$ incubation, which indicated

Table 3. Nutrient concentrations in Great South Bay (GSB) during BT bloom and in subtidal groundwater and sediment porewater from BTprone embayments. Values reported as means and SD of analytical triplicates in $\mu \mathrm{M} \mathrm{N}$ or $\mu \mathrm{M}$ P. TDN $=$ total dissolved nitrogen $; \quad \mathrm{DON}=$ dissolved organic nitrogen

\begin{tabular}{|lrcccr|}
\hline & $\mathrm{TDN}$ & $\mathrm{NO}_{3}{ }^{-}$ & $\mathrm{NH}_{4}{ }^{+}$ & $\mathrm{DON}$ & ${\mathrm{o}-\mathrm{PO}_{4}{ }^{3-}}^{-}$ \\
\hline GSB & 29 & $2.8(0.16)$ & $0.27(0.03)$ & $26(0.17)$ & $0.28(0.05)$ \\
Groundwater & 330 & $320(3.9)$ & $0.83(0.05)$ & $9.1(1.2)$ & $0.55(0.12)$ \\
Porewater & 230 & $0.6(0.85)$ & $130(21)$ & $100(6.4)$ & $3.9(0.60)$ \\
\hline
\end{tabular}


that the entire phytoplankton community declined without nutrient amendments (Fig. 5). In contrast, chl a increased to 21 and $23 \mu \mathrm{g} \mathrm{l}^{-1}$ in samples amended with groundwater or porewater (Fig. 5) and was at significantly greater levels than in control treatments by $72 \mathrm{~h}$ ( $p<0.05$; Tukey test). While groundwater and porewater treatments contained similar amounts of chl a

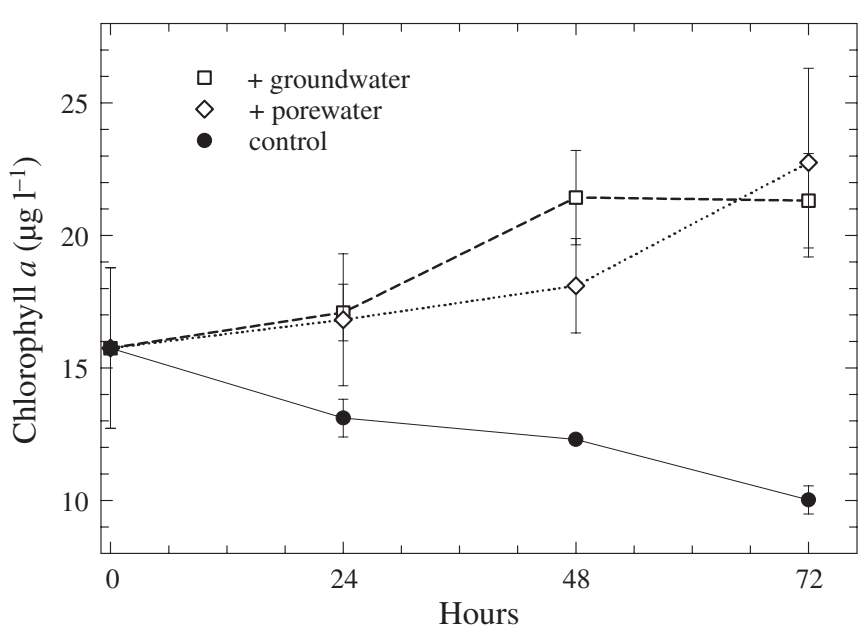

Fig. 5. Time courses of chl a production in water samples collected from Bay Shore Cove and Great South Bay on 24 June 2001, amended with coastal groundwater or benthic porewater or not amended. Error bars represent SD from triplicate filtrations

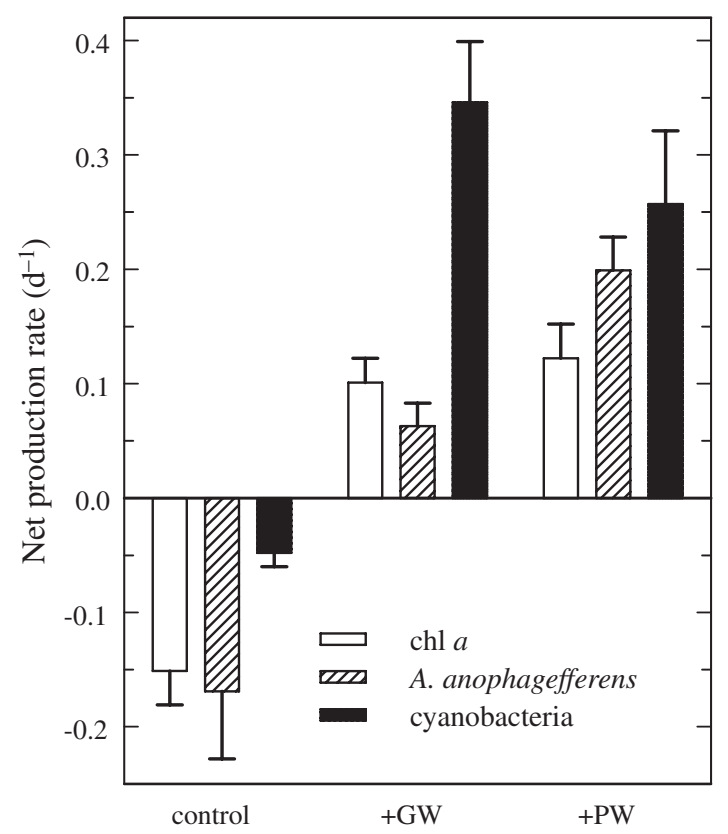

Fig. 6. Net production rates of total phytoplankton community (chl a), Aureococcus anophagefferens, and cyanobacteria in unaltered bay water and replicate samples amended with coastal groundwater (GW) or benthic porewater (PW). Net production rate $=$ growth rate - mortality rate. Error bars represent $1 \mathrm{SD}$
( $p$ > 0.05), suggesting comparable community growth, microscopic observations revealed a differential effect between these treatments (Fig. 6). Net production rates (growth - mortality) of cyanobacteria during $72 \mathrm{~h}$ incubations with groundwater were significantly faster than those with porewater ( $p<0.05$; Tukey test). The response of Aureococcus anophagefferens to these amendments was just the opposite. Its growth in the porewater-amended treatment was significantly greater than its rate in the groundwater-amended treatment and control $(\mathrm{p}<0.05)$. Net production of both $A$. anophagefferens and cyanobacteria was stimulated by additions of porewater to a greater degree than the total phytoplankton community (chl a), which suggested that these plankters would numerically dominate over time.

\section{DISCUSSION}

\section{Dissolved nitrogen in Long Island embayments}

Coastal eutrophication has often been cited as the primary cause for escalating global frequencies of harmful algal blooms (Smayda 1990, Paerl 1997, Anderson et al. 2002). Antithetically, temporal and spatial mismatches observed between Aureococcus anophagefferens blooms and dissolved nutrient distributions argue against a direct link between eutrophication and BT onset (Cosper et al. 1989a,b, Keller \& Rice 1989, LaRoche et al. 1997, Gobler \& SañudoWilhelmy 2001a). In bays which host $\mathrm{BT}, \mathrm{NO}_{3}{ }^{-}$concentrations may be as high as $30 \mu \mathrm{M}$ in spring, but decline well below $5 \mu \mathrm{M}$ for most of the summer and fall when BT typically becomes apparent. In these same embayments, DON concentrations vary between 10 and $50 \mu \mathrm{M}$ N throughout the warm seasons (LaRoche et al. 1997, Gobler \& Sañudo-Wilhelmy 2001a, Gobler et al. 2002), and typically comprise 60 to $90 \%$ of the longterm averages for dissolved nitrogen inventories (SCDHS 1976-2001). However, composition of these DON pools is not known and bioavailability may be highly variable (Antia et al. 1991).

Is it possible that changes in nitrogen loadings or speciation could be responsible for recurring BT in Long Island embayments since 1985? An instructive approach is to evaluate whether nitrogenous nutrients in coastal waters were systematically different prior to 1985 (pre-BT era) relative to a comparable time interval after the onset of BT (post-1985). Median DIN and DON concentrations in 2 affected Long Island embayments (Peconic and Moriches; Fig. 1) have not been systematically higher in the post-BT era than they were prior to 1985, even though DON concentrations at 2 stations in the Peconic Bay were elevated 
(Table 4). In contrast, DIN concentrations at 4 Great South Bay stations were significantly higher from 1985 to 1993 than from 1976 to 1984 (no such differences were observed in DON pools) (Table 4). On average, $\mathrm{NH}_{4}{ }^{+}$comprised 21 to $70 \%$ of DIN inventories at stations listed in Table 4, and significant differences were observed between pre- and post-BT datasets for $70 \%$ of the stations. However, stations were as likely to show decreases in $\mathrm{NH}_{4}{ }^{+}$concentrations as they were to exhibit increases (data not shown). Median Kjeldahl total $\mathrm{N}$ concentrations varied from 16 to $57 \mu \mathrm{M} \mathrm{N}$, and only 2 of the 17 stations exhibited marginally higher total $\mathrm{N}$ concentrations (dissolved + particulate) in the post-BT era (SCDHS 1976-2001). Total N concentrations were not significantly different between these periods at the remaining stations (not presented). The fact that total $\mathrm{N}$ concentrations did not statistically vary between sampling periods argues that the post-BT water column is not supporting larger $\mathrm{N}$ inventories than it did before 1985, regardless of precise N-speciation. No compelling evidence for shifts in total nitrogen inventories emerged from our analysis of historical nutrient data.

Variations in water column nutrient concentrations are modulated by removal processes, such as trophic transfer, advection, sedimentation, and denitrification, all of which may change in response to nutrient load- ings. Therefore, better assessments of historical changes in removal and nutrient loadings are required to adequately evaluate the eutrophication issue. Most freshwater and nutrients entering these embayments is via SGD (Bokuniewicz 1980, Capone \& Bautista 1985, LaRoche et al. 1997), which is diffuse and highly variable in space and time. Unfortunately, these loadings are poorly quantified due to infrequent and geographically-limited measurements of SGD.

Nitrogen loadings probably have increased as a consequence of increasing human populations, cesspool leaching, and fertilizer application to developed lands (LaRoche et al. 1997, Gobler \& Sañudo-Wilhelmy 2001a). From the limited sites for which data are available, nitrogen nutrients in local groundwaters differed dramatically from those measured in the receiving waters, as exemplified in Table 3. For example, groundwater in monitoring wells on the northern margin of the Peconic Estuary may have as much as 800 and $10 \mu \mathrm{M} \mathrm{N}$ of $\mathrm{NO}_{3}^{-}$and $\mathrm{DON}$, respectively, under spring high-flow conditions (Montluçon \& Sañudo-Wilhelmy 2001). Under low flow conditions, maxima of $\mathrm{NO}_{3}{ }^{-}$and DON shift to 170 and $32 \mu \mathrm{M} \mathrm{N}$, respectively. However, nitrogen loadings and speciation in SGD passing through sediments are altered by microbial processes, depending upon flow rates, temperature, and organic content of sediments. For exam-

Table 4. Comparison of dissolved inorganic nitrogen (DIN $=\mathrm{NO}_{3}^{-}+\mathrm{NO}_{2}^{-}+\mathrm{NH}_{4}{ }^{+}$) and dissolved organic nitrogen $(\mathrm{DON}=$ dissolved Kjeldahl nitrogen - DIN) prior to first reported BT ('pre' = 1976 to 1984) and a comparable period after onset of BT ('post' $=1985$ to 1993). Data from the 2 collection periods compared using Mann-Whitney rank sum test. Those yielding values of p > 0.05 were considered statistically indistinguishable. Peconic, Moriches and GSB (Great South Bay) are major embayments routinely monitored by Suffolk County Department of Health Service's surface water quality program; station numbers are a subset of those monitored. (pre:post) = number of samples analyzed in pre- and post-brown tide periods

\begin{tabular}{|c|c|c|c|c|c|c|c|c|}
\hline Station & $\begin{array}{l}\text { Median } \\
\text { pre }\end{array}$ & $\begin{array}{l}\text { DIN } \\
\text { post }\end{array}$ & $\begin{array}{c}\mathrm{n} \\
\text { (pre:post) }\end{array}$ & $\mathrm{p}$ & $\begin{array}{l}\text { Median } \\
\text { pre }\end{array}$ & $\begin{array}{l}\text { DON } \\
\text { post }\end{array}$ & $\begin{array}{c}\mathrm{n} \\
\text { (pre:post) }\end{array}$ & $\mathrm{p}$ \\
\hline \multicolumn{9}{|l|}{ Peconic } \\
\hline 130 & 0.86 & 1.29 & $(33: 352)$ & ns & 13.29 & 17.36 & (32:352) & $\mathrm{ns}$ \\
\hline 170 & 1.21 & 1.36 & (35:491) & ns & 13.22 & 18.07 & (32:491) & 0.0001 \\
\hline 220 & 1.12 & 1.87 & $(37: 24)$ & ns & 20.84 & 30.38 & $(34: 10)$ & ns \\
\hline 240 & 3.93 & 5.11 & $(41: 37)$ & ns & 16.59 & 29.16 & $(39: 37)$ & 0.003 \\
\hline \multicolumn{9}{|c|}{ Moriches } \\
\hline 100 & 1.64 & 1.64 & $(34: 48)$ & ns & 21.50 & 21.43 & $(33: 48)$ & ns \\
\hline 110 & 2.14 & 2.21 & $(31: 38)$ & ns & 26.12 & 19.21 & $(30: 38)$ & ns \\
\hline 120 & 1.50 & 0.93 & $(33: 46)$ & ns & 24.07 & 17.61 & $(32: 46)$ & ns \\
\hline 130 & 1.50 & 1.50 & $(31: 46)$ & ns & 18.68 & 16.61 & $(30: 46)$ & ns \\
\hline 140 & 2.00 & 1.00 & $(30: 38)$ & 0.035 & 12.86 & 16.43 & $(29: 38)$ & ns \\
\hline 150 & 2.07 & 2.25 & $(34: 50)$ & ns & 15.67 & 16.03 & $(33: 50)$ & ns \\
\hline 160 & 2.14 & 3.04 & $(29: 46)$ & ns & 18.25 & 14.46 & $(28: 46)$ & ns \\
\hline 170 & 3.18 & 3.92 & $(30: 48)$ & ns & 16.86 & 18.36 & $(28: 48)$ & ns \\
\hline \multicolumn{9}{|l|}{ GSB } \\
\hline 110 & 1.35 & 5.43 & $(65: 55)$ & 0.0001 & 25.76 & 24.75 & $(63: 55)$ & ns \\
\hline 120 & 1.21 & 2.50 & $(64: 79)$ & 0.0001 & 26.79 & 21.79 & $(62: 58)$ & ns \\
\hline 130 & 1.71 & 3.79 & $(68: 60)$ & 0.0001 & 28.08 & 22.82 & $(66: 60)$ & ns \\
\hline 150 & 1.14 & 2.43 & $(70: 60)$ & 0.002 & 25.79 & 16.07 & $(77: 60)$ & 0.03 \\
\hline 250 & 8.86 & 4.00 & $(86: 48)$ & ns & 12.11 & 17.07 & $(86: 86)$ & ns \\
\hline
\end{tabular}


ple, when SGD is high in the spring, N-speciation may change little due to short residence times in organicrich sediments, releasing substantial amounts of $\mathrm{NO}_{3}{ }^{-}$ to the bays. In contrast, under summer low flow conditions, denitrifying bacteria may significantly reduce the high $\mathrm{NO}_{3}{ }^{-}$concentrations in SGD as it passes through sediments, releasing $\mathrm{N}_{2}$ and $\mathrm{NH}_{4}{ }^{+}$to overlying waters (Seitzinger 1988). This is exemplified by the nitrogen inventories reported for porewater (Table 3).

\section{Algal responses to $\mathrm{N}$-speciation}

Clearly, relative contributions of inorganic and organic nitrogen species vary seasonally in Long Island embayments (Gobler \& Sañudo-Wilhelmy 2001a). Our experimental results were consistent with the hypothesis that the dominant nitrogen species influences whether BT blooms will occur in Long Island embayments (Keller \& Rice 1989, Nixon et al. 1994, LaRoche et al. 1997, Gobler \& Sañudo-Wilhelmy 2001a). Unlike many co-occurring microalgal species, Aureococcus anophagefferens has qualities consistent with phytoplankton adapted to a more oligotrophic, deep-water environment, such as relatively sensitive functional responses to reduced nitrogenous nutrients $\left(\mathrm{NH}_{4}{ }^{+}\right.$, glutamate, and urea) and relatively low light requirements (Dzurica et al. 1989, Yentsch et al. 1989, Lomas et al. 1996, Milligan \& Cosper 1997, this study). While photoautotrophic and capable of growing solely on inorganic nutrients, $A$. anophagefferens also appears adept at utilizing a variety of dissolved organic nutrients, including proteins, which qualifies it as a mixotroph (Dzurica et al. 1989, Lomas et al. 1996, 2001, Berg et al. 1997, 2002, 2003b, Mulholland et al. 2002). Despite $A$. anophagefferens' rather modest growth potentials $\left(\mu_{\max } \leq 0.80 \mathrm{~d}^{-1}\right)$, its unique combination of attributes may provide competitive advantages over other species and permit the occupation of a turbid niche dominated by reduced nitrogen species.

Consistent with published field and mesocosm observations (Keller \& Rice 1989, Berg et al. 1997, LaRoche et al. 1997, Gobler \& Sañudo-Wilhelmy 2001a, Kana et al. 2004), our simulations predicted that Aureococcus anophagefferens would be the poorest performer of 5 species tested when $\mathrm{NO}_{3}{ }^{-}$overwhelms nitrogen inventories, irrespective of absolute $\mathrm{NO}_{3}{ }^{-}$ concentration. This result agrees well with ${ }^{15} \mathrm{~N}$ experiments that demonstrated that this species obtains only a minute fraction of its total $\mathrm{N}$ requirement from $\mathrm{NO}_{3}{ }^{-}$ (Berg et al. 1997, Mulholland et al. 2002). While A. anophagefferens does grow when provided $\mathrm{NO}_{3}{ }^{-}$as sole $\mathrm{N}$-source, its $\mu_{\max }$ was only $0.30 \mathrm{~d}^{-1}$; in contrast, Thalassiosira pseudonana exhibited a $\mu_{\max }$ of $0.87 \mathrm{~d}^{-1}$ under the same conditions (Table 1). If we extrapolate these results to field conditions, we might expect that phytoplankton communities would consist largely of diatoms, chlorophytes, and cyanobacteria during periods of rapid SGD and high $\mathrm{NO}_{3}{ }^{-}$loadings to embayments, i.e. during the spring and early summer.

Barring other resource limitations, Aureococcus anophagefferens appeared to have a competitive advantage over 4 common co-occurring phytoplankton species when $\mathrm{NH}_{4}{ }^{+}$and DON species (such as glutamate) dominated dissolved nitrogen inventories at low to moderate concentrations. For example, Thalassiosira pseudonana appeared to be unable to grow if only supported by low $\mathrm{NH}_{4}{ }^{+}$or glutamate concentrations, i.e. $S_{\min }$ of 12 to $13 \mu \mathrm{M}$ N. This diatom appeared to possess substrate thresholds below which growth was not supported. We speculate that these thresholds may be a manifestation of low affinities of uptake systems or regulation of uptake system expression.

Our findings agreed well with observations of $\mathrm{N}$ uptake by Aureococcus anophagefferens, which have shown that reduced $\mathrm{N}$ compounds are taken up preferentially, even when nitrate is more abundant (Lomas et al. 1996, Berg et al. 1997, Mulholland et al. 2002). In the case of $\mathrm{NH}_{4}{ }^{+}$, this advantage existed throughout typical coastal concentration ranges. However, ammonium concentrations above $50 \mu \mathrm{M}$ actually repressed growth and thus appeared to be toxic to $A$. anophagefferens, whereas glutamate only became inhibitory above $300 \mu \mathrm{M}$. These inhibitions may clarify why Cosper et al. (1990) and Fan et al. (2003) were unable to grow $A$. anophagefferens in media provided with millimolar $\mathrm{NH}_{4}{ }^{+}$concentrations as the sole $\mathrm{N}$-source. The dominance of $A$. anophagefferens when glutamate was the primary nitrogen source might reflect its ability to obtain cellular carbon, energy, and nitrogen from this compound (Berg et al. 1997, Mulholland et al. 2002). Under low light conditions typical of bloom periods, a phytoplankter such as $A$. anophagefferens that possesses the ability to supplement photosynthetic Cfixation with heterotrophic uptake of dissolved organic matter would have a clear advantage over strictly autotrophic species (Gobler \& Sañudo-Wilhelmy 2001b, Lomas et al. 2001).

Observed growth responses of these 5 phytoplankton species to ammonium and glutamate were consistent with field observations of phytoplankton communities within Long Island estuaries. For example, BT typically occur when ammonium levels are at low to moderate levels $(\leq 10 \mu \mathrm{M})$ and DON compounds are moderately abundant (20 to $100 \mu \mathrm{M} \mathrm{N}$ ) (SCDHS 1976-2001, Berg et al. 1997). This is more than sufficient nitrogen to support a typical BT bloom of $\sim 1.5 \times$ $10^{6} \mathrm{cells} \mathrm{ml}^{-1}$. We determined that our cultured Aureococcus anophagefferens had an average cell content of $0.32 \mathrm{pg} \mathrm{N}$, so a bioavailable pool of only about $35 \mu \mathrm{M}$ 
dissolved $\mathrm{N}$ is required to fuel bloom conditions. This same amount of nitrogen would support half as much Synechococcus bacillaris (0.64 pg $\left.\mathrm{N} \mathrm{cell}^{-1}\right)$ or Prorocentrum minimum $\left(0.66 \mathrm{pg} \mathrm{N}\right.$ cell $\left.^{-1}\right)$, 4 -fold less Nannochloris atomus (1.21 pg N cell $\left.{ }^{-1}\right)$, and 5 -fold fewer Thalassiosira pseudonana (1.69 pg $\mathrm{N} \mathrm{cell}^{-1}$ ). Interestingly, within the more eutrophied zones of Long Island estuaries where ammonium concentrations can exceed $100 \mu \mathrm{M}, \mathrm{BT}$ are absent and phytoplankton communities are dominated by diatoms and dinoflagellates (Gobler \& Boneillo 2003).

Prior to 1983, urea appeared to dominate dissolved nitrogen inventories in Long Island embayments, accounting for $\leq 85 \%$ of total dissolved $\mathrm{N}$ and attaining concentrations as high as $7.5 \mu \mathrm{M}$ (Kaufman et al. 1983). However, concentrations reported more recently have been typically $<0.5 \mu \mathrm{M} \mathrm{N}$ (Berg et al. 1997, Gobler \& Sañudo-Wilhelmy 2001b). Long-term urea abatements probably reflect the abandonment of intensive duck farming along coasts of bays and tributaries, and decimation of shellfish beds (hard clams, bay scallops) (LaRoche et al. 1997). Urea also enters groundwater through application of fertilizer and deicing agents within the watershed (Lomas et al. 2001). However, urea concentrations in the few groundwater samples analyzed in this system appear to be very low near submarine groundwater discharge areas (C. J. Gobler unpubl. data).

Responses of our simulated phytoplankton community to environmentally realistic concentrations of urea $(\leq 10 \mu \mathrm{M} \mathrm{N})$ differed from its response to other N-species. Thalassiosira pseudonana dominated the model community, followed by Aureococcus anophagefferens (Table 2). Field populations of $A$. anophagefferens have been shown to have high affinities and rapid specific uptake rates for urea (Lomas et al. 1996). However, Dzurica et al.'s (1989) and our results demonstrated that an acclimation period is necessary for $A$. anophagefferens to express maximal growth when presented with urea after growing on $\mathrm{NO}_{3}{ }^{-}$. While intracellular hydrolytic ureases appear to be constitutive in A. anophagefferens and Prorocentrum minimum (Fan et al. 2003), transmembrane transporters may not be. Regardless of $\mathrm{N}$-source $\left(\mathrm{NO}_{3}{ }^{-}, \mathrm{NH}_{4}{ }^{+}\right.$, urea) used in the study by Fan et al. (2003), urease activity in these algae increased proportionately with growth rate; this did not hold for the diatom Thalassiosira weissflogii. Delays in A. anophagefferens' response to increasing urea concentrations may simply result from regulation of uptake systems rather than kinetic properties of intracellular urease. Such delays may place $A$. anophagefferens at a competitive disadvantage compared with other microalgae, which possess lower induction thresholds or constitutive high-affinity uptake pathways.
It is notable that, in addition to Aureococcus anophagefferens, 2 other algal species that we examined (Prorocentrum minimum and Nannochloris atomus) are known to cause harmful algal blooms. In the 1950s and later, green tide blooms of Nannochloris spp. plagued numerous embayments along the south shore of Long Island and eliminated the once profitable oyster fishery there (Ryther 1954). Our demonstration that $N$. atomus was quite competitive at the highest concentrations of all forms of nitrogen is consistent with previous studies that concluded that green tide blooms arose in highly eutrophied sub-estuaries contaminated by duck farm effluents (Ryther 1954). Moreover, our results argued that subsequent abandonment of duck farms and transition of these bays to a less eutrophic condition in recent decades (Ryther 1989) set the stage for a switch in the dominant alga from Nannochloris spp. to A. anophagefferens (LaRoche et al. 1997).

Recently, Prorocentrum minimum was grouped along with Aureococcus anophagefferens and other phytoplankton into a category of harmful algae that seem to initiate blooms under high DOC:DON ratio conditions (Glibert et al. 2001, Anderson et al. 2002). Our observation of high Prorocentrum minimum and A. anophagefferens growth performance under low to moderate levels of glutamate (Table 2) supports this categorization.

\section{Field validation}

Our field validation experiments were conducted to determine how the dominant nutrient reservoirs (groundwater and benthic porewater), distinguished by their $\mathrm{N}$-speciation, influence a natural algal assemblage already dominated by Aureococcus anophagefferens. Although our experiments were designed to deliver equal amounts of nitrogen, both porewater and groundwater obviously contain a host of non-nitrogenous constituents that may have also influenced algal growth rates. The indistinguishable chl a yield in baywater amended with porewater or groundwater argues against P-limitation in our samples, because benthic porewater contained 7 -fold more o- $\mathrm{PO}_{4}{ }^{3-}$ than groundwater (Fig. 5, Table 3). Furthermore, chronic N-limitation has been reported for these Long Island estuaries (Ryther \& Dunstan 1971, Gobler \& Sañudo-Wilhemly 2001a, Gobler et al. 2002). Therefore, nitrogen within the porewater and groundwater appears to be primarily responsible for growth in these treatments.

Results from these field experiments are coherent with our laboratory results and growth performance simulations. Specifically, porewater amendments (which contained primarily reduced $\mathrm{N}$ species) yielded higher cell densities of Aureococcus anophagefferens 
relative to groundwater amendments (which contained nitrate almost exclusively). Conversely, cyanobacteria, which were likely dominated by Synechococcus sp. at this time of year (Campbell et al. 1983, Gobler et al. 2004), grew more rapidly in nitrate-rich groundwater amendments than in benthic porewater amendments. All results reported above are consistent with the hypothesis that moderate effluxes of reduced $\mathrm{N}$ from sediments favor BT proliferation in Long Island estuaries over blooms of competing phytoplankters (LaRoche et al. 1997, Gobler \& Sañudo-Wilhelmy 2001a, Lomas et al. 2004, MacIntyre et al. 2004). In addition to reduced nitrogen, $A$. anophagefferens growth may also be stimulated by organic carbon enrichments provided by porewater amendments (Burdige \& Homstead 1994, Lomas et al. 1996, 2001, Berg et al. 1997, 2002, 2003b).

\section{CONCLUSIONS}

Our experimental approach did not account for other ecological factors that all undoubtedly influence BT dynamics, such as: prey selectivity by suspension feeders, toxic contaminants, micronutrients, allelopathic inhibition, or variability in nutrient supply (Bricelj \& Lonsdale 1997, Caron et al. 2004). Nonetheless, our results were consistent with previous field, mesocosm and laboratory observations, which suggested that nitrogen speciation is a significant determinant in establishing dominance of Aureococcus anophagefferens. Behavior of $A$. anophagefferens in our grow out experiments supported its portrayal as a mixotroph and a relatively oligotrophic member of coastal phytoplankton communities. Our simulations suggested that proliferation of $A$. anophagefferens is favored in environments with low to moderate loadings of reduced DIN and organic nitrogen species (1 to $50 \mathrm{\mu M} \mathrm{NH}_{4}{ }^{+}$, glutamate, and possibly urea), but not in those dominated by $\mathrm{NO}_{3}^{-}$. In fact, at moderate to high nutrient concentrations, A. anophagefferens grows at significantly slower rates than all other co-occurring microalgal species tested.

Characterization of BT as a secondary bloom fueled by nitrogen regenerated by planktonic and sedimentary processes is mostly consistent with available data (LaRoche et al. 1997, Gobler \& Sañudo-Wilhelmy 2001a, Kana et al. 2004, Lomas et al. 2004, MacIntyre et al. 2004). However, if we accept nitrogen speciation as a major factor influencing BT onset, then the following question still remains: how different were systemwide nitrogen dynamics in the pre-BT era compared to today? We can only speculate that perhaps these bays responded non-linearly to alterations in coastal eutrophication, whereby they shifted to a new opera- tional state after some threshold in nutrient input or nutrient compositional change was surpassed. In this scenario, increased nutrient loadings may have caused intensification of primary spring blooms (mixed algal assemblages) beyond the system's abilities to denitrify or export fixed nitrogen offshore. In this state (post1985?), residual reduced nitrogen attained sufficient levels to support secondary BT blooms in the summer. Historical nutrient and chl a datasets (SCDHS 1976-2001) neither support nor refute this hypothesis, because temporal sampling resolution is too coarse and very little information on loading or removal rates is available. Furthermore, this interpretation still begs the question: what sets Long Island embayments apart from other coastal sites in the western North Atlantic that are only subject to sporadic BT outbreaks? With incomplete nitrogen inventories, sparse nitrogen loading data, and no denitrification measurements, answering questions regarding altered nitrogen dynamics is presently beyond our reach.

Acknowledgments. We are indebted to A. Modanesi, K. Goodrich, and D. Escribano for their technical assistance. We thank R. Nuzzi (Suffolk County Department of Health Services [SCDHS]) for data, analytical services, and guidance. This research was supported by Peconic Estuary Program Office, SCDHS (contract \# 525-8228-0113-00-00001). Contribution No. 1315 of the Marine Sciences Research Center of Stony Brook University.

\section{LITERATURE CITED}

Aller RC, Benninger LK (1981) Spatial and temporal patterns of dissolved ammonium, manganese, and silica fluxes from bottom sediments of Long Island Sound, USA. J Mar Res 39:295-314

Anderson DM, Kulis DM, Cosper EM (1989) Immunofluorescent detection of the 'brown tide' organism, Aureococcus anophagefferens. Lect Notes Coast Estuar Stud 35: 213-228

Anderson DM, Glibert PM, Burkholder JM (2002) Harmful algal blooms and eutrophication: nutrient sources, composition and consequences. Estuaries 4B:704-726

Antia NJ, Harrison PJ, Oliveria L (1991) The role of dissolved organic nitrogen in phytoplankton nutrition, cell biology and ecology. Phycologia 30:1-89

Berg GM, Glibert PM, Jørgensen NOG, Lomas MW, Burford M (1997) Organic nitrogen uptake and growth by the chrysophyte, Aureococcus anophagefferens during a brown tide event. Mar Biol 129:377-387

Berg GM, Glibert PM, Jørgensen NOG, Balode M, Purina I (2001) Variability in inorganic and organic nitrogen uptake associated with riverine nutrient input in the Gulf of Riga, Baltic Sea. Estuaries 24:204-214

Berg GM, Repeta DJ, LaRoche J (2002) Dissolved organic nitrogen hydrolysis rates in axenic cultures of Aureococcus anophagefferens (Pelagophyceae): comparison with heterotrophic bacteria. Appl Environ Microbiol 68: 401-404

Berg GM, Balode M, Purina I, Bekere S, Béchemin C, Maestrini SY (2003a) Plankton community composition in 
relation to availability and uptake of oxidized and reduced nitrogen. Aquat Microb Ecol 30:263-274

Berg GM, Repeta DJ, LaRoche J (2003b) The role of the picoeukaryote Aureococcus anophagefferens in cycling of marine high-molecular weight dissolved organic nitrogen. Limnol Oceanogr 48:1825-1830

Berges JA, Montagnes DJS, Hurd CL, Harrison PJ (1994) Fitting ecological and physiological data to rectangular hyperbolae: a comparison of methods using Monte Carlo simulations. Mar Ecol Prog Ser 114:175-183

Bokuniewicz H (1980) Groundwater seepage into Great South Bay, New York. Estuar Coast Shelf Sci 10:437-444

Bricelj VM, Lonsdale DJ (1997) Aureococcus anophagefferens: Causes and ecological consequences of brown tides in U.S. mid-Atlantic coastal waters. Limnol Oceanogr 42: 1023-1038

Brzezinski MA (1985) The Si:C:N ratio of marine diatoms: interspecific variability and the effect of some environmental variables. J Phycol 21:347-357

Burdige DJ, Homstead J (1994) Fluxes of dissolved organic carbon from Chesapeake Bay sediments. Geochim Cosmochim Acta 58:3407-3424

Campbell L, Carpenter EJ, Iacono VJ (1983) Identification and enumeration of marine chroococcoid cyanobacteria by immunofluorescence. Appl Environ Microbiol 46: 553-559

Capone DG, Bautista MF (1985) A groundwater source of nitrate in nearshore marine sediments. Nature 313: 214-216

Carlsson P, Granéli E (1999) Effects of N:P:Si ratios and zooplankton grazing on phytoplankton communities in the northern Adriatic Sea. II. Phytoplankton species composition. Aquat Microb Ecol 18:55-65

Carlsson P, Edling H, Bechemin C (1998) Interactions between a marine dinoflagellate (Alexandrium catenella) and a bacterial community utilizing riverine humic substances. Aquat Microb Ecol 16:65-80

Caron DA, Gobler CJ, Lonsdale DJ, Cerrato RM and 6 others (2004) Microbial herbivory on the brown tide alga, Aureococcus anophagefferens: results from natural ecosystems, mesocosms and laboratory experiments. Harmful Algae 3: 439-457

Carpenter EJ, Dunham S (1985) Nitrogenous nutrient uptake, primary production, and species composition of phytoplankton in th Carmans River estuary, Long Island, New York. Limnol Oceanogr 30:513-526

Chang J, Carpenter EJ (1985) Blooms of the dinoflagellate Gyrodinium aureoleum in a Long Island estuary-box model analysis of bloom maintenance. Mar Biol 89:83-93

Collos YA, Vaquer B, Bibent G, Slawyk G, Garcia N, Souchou $P$ (1997) Variability in nitrate uptake kinetics of phytoplankton communities in a Mediterranean Coastal lagoon. Estuar Coastal Shelf Sci 44:369-375

Cosper EM, Dennison WC, Carpenter EJ, Bricelj VM, Mitchell JG, Kuenster SH, Coleflesh D, Dewey M (1987) Recurrent and persistent brown tide blooms perturb coastal marine ecosystem. Estuaries 10:284-290

Cosper EM, Dennison WC, Milligan AJ, Carpenter EJ, Lee C, Holzapfel J, Milanese L (1989a) An examination of the environmental factors important to initiating and sustaining 'brown tide' blooms. In: Cosper EM, Bricelj VM, Carpenter EJ (eds) Novel phytoplankton blooms: causes and impacts of recurrent brown tides and other unusual blooms. Springer-Verlag, Berlin, p 317-340

Cosper EM, Carpenter EJ, Cottrell M (1989b) Primary productivity and growth dynamics of the 'brown tide' in Long Island embayments. In: Cosper EM, Bricelj VM, Carpenter
EJ (eds) Novel phytoplankton blooms: causes and impacts of recurrent brown tides and other unusual blooms. Springer-Verlag, Berlin, p 139-158

Cosper EM, Lee C, Carpenter EJ (1990) Novel 'brown tide' blooms in Long Island embayments: a search for the causes. In: Granelli E, Sundstrom B, Edler L, Anderson DM (eds) Toxic marine phytoplankton. Elsevier, New York, p 17-28

Cosper EM, Gary RT, Milligan AJ, Doall MH (1993) Iron, selenium and citric acid are critical to the growth of the "brown tide' microalga, Aureococcus anophagefferens. In: Smayda TJ, Shimizu Y (eds) Toxic phytoplankton blooms in the sea. Elsevier, New York, p 667-673

Dzurica S, Lee C, Cosper EM, Carpenter EJ (1989) Role of environmental variables, specifically organic compounds and micronutrients, in the growth of the Chrysophyte Aureococcus anophagefferens, the 'brown tide' microalgae. In: Cosper EM, Bricelj VM, Carpenter EJ (eds) Novel phytoplankton blooms: causes and impacts of recurrent brown tides and other unusual blooms. Springer-Verlag, Berlin, p 229-252

Fan C, Glibert PM, Alexander J, Lomas MW (2003) Characterization of urease activity in three marine phytoplankton species, Aureococcus anophagefferens, Prorocentrum minimum, and Thalassiosira weissflogii. Mar Biol 142: 949-958

Fogg GE, Thake B (1987) Algal cultures and phytoplankton ecology. University of Wisconsin Press, Madison, WI

Glibert PM, Magnien R, Lomas MW, Alexander J, Fan C, Haramoto E, Trice M, Kana TM (2001) Harmful algal blooms in the Chesapeake and coastal bays of Maryland, USA: comparison of 1997, 1998, and 1999 events. Estuaries 24:875-883

Gobler CG, Boneillo GE (2003) Impacts of anthropogenically influenced groundwater seepage on water chemistry and phytoplankton dynamics within a coastal marine system. Mar Ecol Prog Ser 255:101-114

Gobler CG, Cosper EM (1996) Stimulation of 'brown tide' blooms by iron. In: Yasumoto T, Oshima Y, Fukuyo Y (eds) Harmful and toxic algal blooms. UNESCO, Paris, p 321-324

Gobler CG, Sañudo-Wilhelmy SA (2001a) Temporal variability of groundwater seepage and brown tide blooms in a Long Island embayment. Mar Ecol Prog Ser 217:299-309

Gobler CG, Sañudo-Wilhelmy SA (2001b) Effects of organic carbon, organic nitrogen, inorganic nutrients, and iron additions on the growth of phytoplankton and bacteria during a brown tide bloom. Mar Ecol Prog Ser 209:19-34

Gobler CG, Renaghan MJ, Buck NJ (2002) Impacts of nutrients and grazing mortality on the abundance of Aureococcus anophagefferens during a New York brown tide bloom. Limnol Oceanogr 47:129-141

Gobler CJ, Boneillo GE, Debenham C, Caron DA (2004) Nutrient limitation, organic matter cycling, and plankton dynamics during an Aureococcus anophagefferens bloom. Aquat Microb Ecol 35:31-43

Guillard RRL, Ryther JH (1962) Studies of marine planktonic diatoms. I. Cyclotella nana Hustedt, and Detonula confervacea (Cleve) Gran. Can J Microbiol 8:229-239

Healey FP (1980) Slope of the Monod equation as an indicator of advantage in nutrient competition. Microb Ecol 5:281-286

Jones MN (1984) Nitrate reduction by shaking with cadmium: alternative to cadmium columns. Water Res 18:643-646

Kana TM, Lomas MW, MacIntyre HL, Cornwell JC, Gobler CJ (2004) Stimulation of the brown tide organism, Aureococcus anophagefferens, by selective nutrient additions to in situ mesocosms. Harmful Algae 3:377-388 
Kaufman ZG, Lively JS Carpenter EJ (1983) Uptake of nitrogenous nutrients by phytoplankton in a barrier island estuary: Great South Bay, New York. Estuar Coast Shelf Sci 17:483-493

Keller AA, Rice RL (1998) Effects of nutrient enrichment on natural populations of the brown tide phytoplankton Aureococcus anophagefferens (Chrysophyceae). J Phycol 25:636-646

Kovarova K, Zehnder AJB, Egli T (1996) Temperature-dependent growth kinetics of Eschericia coli ML 30 in glucoselimited continuous culture. J Bacteriol 178:4530-4539

LaRoche J, Nuzzi R, Waters R, Wyman K, Falkowski PG, Wallace DWR (1997) Brown tide blooms in Long Island's coastal waters linked to variability in groundwater flow. Global Change Biol 3:397-410

Lomas MW, Glibert PM, Berg GM, Burford M (1996) Characterization of nitrogen uptake by natural populations of Aureococcus anophagefferens (Chrysophyceae) as a function of incubation duration, substrate concentration, light and temperature. J Phycol 32:907-916

Lomas MW, Glibert PM, Clougherty DA, Huber DR, Jones J, Alexander J, Haramoto E (2001) Elevated organic nutrient ratios associated with brown tide algal blooms of Aureococcus anophagefferens (Pelagophyceae). J Plankton Res 23:1339-1344

Lomas MW, Kana TM, MacIntyre HL, Cornwell JC (2004) Interannual variability of Aureococcus anophagefferens in Quantuck Bay Long Island: natural test of the DON hypothesis. Harmful Algae 3:389-402

MacIntyre HL, Lomas MW, Cornwell JC, Suggett D, Gobler CJ, Koch E, Kana TM (2004) Mediation of benthic-pelagic coupling by microphytobenthos: an energy and nutrient based model for initiation of blooms of Aureococcus anophagefferens. Harmful Algae 3:403-437

MacIsaac EA, Stockner JG (1993) Enumeration of phototrophic picoplankton by autofluorescence microscopy. In: Kemp PF, Sherr BF, Sherr EB, Cole JJ (eds) Handbook of methods in aquatic microbial ecology. Lewis Publications, Boca Raton, FL, p 187-197

Milligan AJ, Cosper EM (1997) Growth and photosynthesis of the 'brown tide' microalga Aureococcus anophagefferens in subsaturating constant and fluctuating irradiance. Mar Ecol Prog Ser 153:67-75

Montluçon D, Sañudo-Wilhelmy SA (2001) Influence of groundwater discharge on the chemical composition of a coastal environment: Flanders Bay, Long Island, New York. Environ Sci Technol 35:480-486

Mulholland MR, Gobler CJ, Lee C (2002) Peptide hydrolysis, amino acid oxidation and $\mathrm{N}$ uptake in communities seasonally dominated by Aureococcus anophagefferens. Limnol Oceanogr 47:1094-1108

Nixon SW, Granger SL, Taylor DI, Johnson PW, Buckley BA (1994) Subtidal volume fluxes, nutrient inputs and the brown tide - an alternative hypothesis. Estuar Coast Shelf Sci 39:303-312

Paerl HW (1997) Coastal eutrophication and harmful algal blooms: importance of atmospheric deposition and groundwater as 'new' nitrogen and other nutrient sources. Limnol Oceanogr 42:1154-1165

Parsons TR, Maita Y, Lalli CM (1984) A manual of chemical

Editorial responsibility: Yves Collos (Contributing Editor), Montpellier, France and biological methods for seawater analysis. Pergamon Press, Oxford

Porter KG, Feig YS (1980) The use of DAPI for identifying and counting microflora. Limnol Oceanogr 25:943-948

Ryther JH (1954) The ecology of phytoplankton blooms in Moriches Bay and Great South Bay. Biol Bull (Woods Hole) 106:198-209

Ryther JH (1989) Historical perspective of phytoplankton blooms on Long Island and the green tides of the 1950's. In: Cosper EM, Bricelj VM, Carpenter EJ (eds) Novel phytoplankton blooms: causes and impacts of recurrent brown tides and other unusual blooms. Springer-Verlag, Berlin, p 377-383

Ryther JH, Dunstan WM (1971) Nitrogen, phosphorus, and eutrophication in the coastal marine environment. Science 171:1008-1013

SCDHS (Suffolk County Department of Health Services) (1976-2001) Office of Ecology's annual reports of water quality. SCDHS, Riverhead, NY

Schöllhorn E, Granéli E (1996) Influence of different nitrogen to silica ratios and artificial mixing on the structure of a summer phytoplankton community from the Swedish west coast (Gullmar Fjord). J Sea Res 35:159-167

Seitzinger SP (1988) Denitrification in fresh-water and coastal marine ecosystems - ecological and geochemical significance. Limnol Oceanogr 33:702-724

Sharp JH (1991) Total mass and particulate carbon, nitrogen and phosphorus. In: Hurd DC, Spencer DW (eds) Marine particles: analysis and characterization. Geophysical Monograph 63. Am Geophys Union, Washington, DC, p 87-90

Smayda TJ (1989) Primary production and the global epidemic of phytoplankton blooms in the sea: a linkage? In: Cosper EM, Bricelj VM, Carpenter EJ (eds) Novel phytoplankton blooms: causes and impacts of recurrent brown tides and other unusual blooms. Springer-Verlag, Berlin, p 449-483

Smayda TJ (1990) Novel and nuisance phytoplankton blooms in the sea: evidence for a global epidemic. In: Granéli E, Sundström B, Edler L, Anderson DM (eds) Toxic marine phytoplankton. Elsevier, New York, p 29-40

Tilman D (1976) Ecological competition between algae: experimental confirmation of resource-based competition theory. Science 192:463-465

Tilman D (1982) Resource competition and community structure. Princeton University Press, Princeton, NJ

Valderrama JC (1981) The simultaneous analysis of total nitrogen and phosphorus in natural waters. Mar Chem 10: 109-122

Vrede K, Heldal M, Norland S, Bratbak G (2002) Elemental composition $(\mathrm{C}, \mathrm{N}, \mathrm{P})$ and cell volume of exponentially growing and nutrient-limited bacterioplankton. Appl Environ Microbiol 68:2965-2971

Yentsch CS, Phinney DA, Shapiro LP (1989) Absorption and fluorescent characteristics of the brown tide chrysophyte. Its role on light reduction in coastal marine environments. In: Cosper EM, Bricelj VM, Carpenter EJ (eds) Novel phytoplankton blooms: causes and impacts of recurrent brown tides and other unusual blooms. Springer-Verlag, Berlin, p 77-85

Submitted: May 11, 2004; Accepted: September 14, 2005

Proofs received from author(s): March 16, 2006 